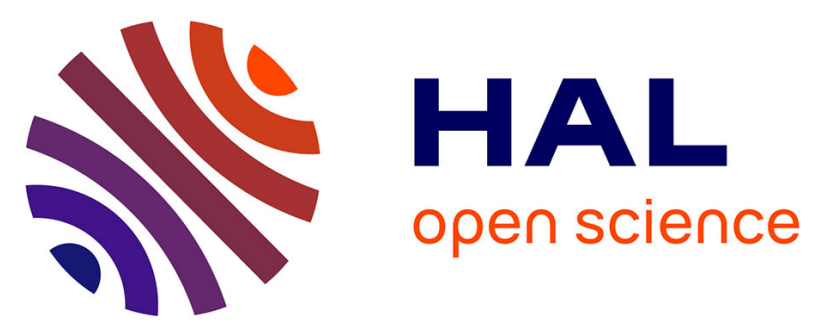

\title{
Amphiphilic Macromolecules on Cell Membranes: From Protective Layers to Controlled Permeabilization.
}

\author{
E. Marie, S. Sagan, Sophie Cribier, C. Tribet
}

\section{To cite this version:}

E. Marie, S. Sagan, Sophie Cribier, C. Tribet. Amphiphilic Macromolecules on Cell Membranes: From Protective Layers to Controlled Permeabilization.. Journal of Membrane Biology, 2014, 247 (9), pp.861-881. 10.1007/s00232-014-9679-3 . hal-01010848

\section{HAL Id: hal-01010848 \\ https://hal.science/hal-01010848}

Submitted on 11 Oct 2019

HAL is a multi-disciplinary open access archive for the deposit and dissemination of scientific research documents, whether they are published or not. The documents may come from teaching and research institutions in France or abroad, or from public or private research centers.
L'archive ouverte pluridisciplinaire HAL, est destinée au dépôt et à la diffusion de documents scientifiques de niveau recherche, publiés ou non, émanant des établissements d'enseignement et de recherche français ou étrangers, des laboratoires publics ou privés. 


\title{
Amphiphilic macromolecules on cell membranes : from protective layers to controlled permeabilization.
}

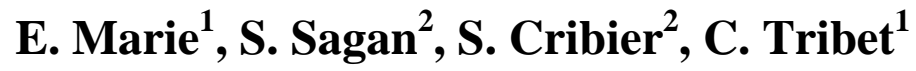 \\ ${ }^{1}$ Ecole Normale Supérieure, Département de Chimie, \\ UMR 8640 CNRS-ENS-UPMC, 24, rue Lhomond, 75005 Paris France \\ ${ }^{2}$ Sorbonne Universités - UPMC Univ Paris 06, École Normale Supérieure-PSL University, \\ Département de Chimie, CNRS, LBM, 4 Place Jussieu, F-75005, Paris, France
}

Keywords : amphiphilic polymers, amphipols, antimicrobial and cell penetrating peptides, cell membrane permeabilization.

Running title : Amphiphilic macromolecules on cell membranes.

Review article destined to the special issue of J. Memb. Biol. on amphipols 


\begin{abstract}
Antimicrobial and cell-penetrating peptides have inspired developments of abiotic membraneactive polymers that can coat, penetrate, or break lipid bilayers in model systems. Application to cell cultures is more recent, but remarkable bioactivities are already reported. Synthetic polymer chains were tailored to achieve i/ high biocide efficiencies, and selectivity for bacteria (Gram-positive/Gram-negative or bacterial/mammalian membranes), ii/ stable and mild encapsulation of viable isolated cells to escape immune systems, iii/ $\mathrm{pH}-$, temperature-, or light-triggered interaction with cells. This review illustrates these recent achievements highlighting the use of abiotic polymers, and compares the major structural determinants that control efficiency of polymers and peptides. Charge density, sp. of cationic and guanidinium side groups, and hydrophobicity (including polarity of stimuli-responsive moieties) guide the design of new copolymers for the handling of cell membranes. While polycationic chains are generally used as biocidal or hemolytic agents, anionic amphiphilic polymers, including Amphipols, are particularly prone to mild permeabilization and/or intracell delivery.
\end{abstract}

\title{
Introduction
}

Controlled perturbation of lipid membranes upon interaction with macromolecules is of enormous importance, both to fundamental studies in membrane biophysics and to practical applications including developments of cost-effective antimicrobial compounds (MunozBonilla A et al. 2012), design of drug-loaded particles (Hu XL et al. 2009; Liechty WB et al. 2010; Nicolas J et al. 2013), or advanced biofunctional capsules (Allen TM et al. 2013; Matile S et al. 2011; Torchilin VP 2012; Yessine MA et al. 2004) that prevail in the currently approved drug-delivery systems. Various water-soluble compounds can be used to affect lipid membranes and cell membranes properties. They generally belong to the class of amphiphilic molecules, having a significant affinity for both aqueous and apolar environments. For instance, detergent molecules partition into lipid bilayers and can break membranes, or solubilize membrane proteins, when their concentration reaches critical values (le Maire $\mathrm{M}$ et al. 2000). Amphiphilic copolymers, and specifically Amphipols, share many similarities with detergents (self-assemblies into micelle-like globules, hydrophobic binding, binding to interfaces, solubilization of lipids and membrane proteins) (Popot JL et al. 2011), (Giusti F et al. 2012) and form mixed assemblies with detergents and lipids (Ladaviere $\mathrm{C}$ et al. 2002),(Popot JL et al. 2011). It is thus not surprising that they could similarly be used as a tool to control cell membranes. Amphiphilic block copolymers may also affect cell membranes, (Huin C et al. 2011; Yang Z et al. 2008) but to date most studies on this latter class of macromolecules were done in vitro on model lipid bilayers. 
In vitro, model systems based on mixtures of polymer and liposomes have been extensively investigated and their properties are summarized in recent reviews (Tribet $\mathrm{C}$ et al. 2008) (Binder WH et al. 2003; Schulz M et al. 2012). Hydrophilic polymers attached to lipid bilayers were shown to form a protective (repulsive) corona that enhanced the circulation time of liposomal formulations in vivo, and may substitute for glycolipids and glycoproteins. Interactions between lipid-anchored macromolecules confer also to the layer above the membrane, high viscosity and/or visco-elastic properties, and affect budding or invagination. Non covalent attractions between lipids and segments in macromolecules can locally perturb the composition of bilayers (formation of domains), lipid organization (scrambling, translocations), or stabilize local curvatures (e.g. formation of pores). Poly(propylene oxide)b-poly(ethylene oxide) block copolymer, usually noted PPO-PEO, can be incorporated in DPPC membranes and lead to a transition from a fluid lipid phase to a more rigid liquidcondensed (LC) one. Infrared Reflection Absorption Spectroscopy and Brewster Angle Microscopy allowed to get insight into the molecular organization of the lipid membrane in the presence of artificial block copolymers (Amado, 2008; Amado, 2009) or diblock peptides (Blume, 2013; Travkora, 2013). Mixed lipid/polymer membranes are generally not homogeneous and demix into lipid-rich clusters and polymer-rich domains. The effect of polymer to lipid ratio, and bilayer fluidity or rigidity on completion of the phase separation has been documented (Chemin, 2012; Le Meins 2013; Olubummo 2013). In contrast, the mixing with lipids is more easily made homogeneous with Amphipols and a variety of other amphiphilic macromolecules having short hydrophobic side groups (and no long hydrophobic block), including natural and non natural amphiphilic peptides and anti-bacterial peptides (Epand RF et al. 2011).

In general, interaction between polymers and lipid membranes proceed from complex interplay between hydrophobic binding, coulombic contributions, self-assemblies, and possible additional effects (e.g. effect of structural constraints) that are specific to the case of peptides (e.g. due to secondary/tertiary folding, (Khandelia $\mathrm{H}$ et al. 2008)) or block copolymers. Amphiphilic peptides represent the class of macromolecules that could be design with the highest degree of control (chain length, sequence, folding) (Bechinger B et al. 2012a). In comparison, the synthetic amphiphilic copolymers are devoid of secondary structure, and present higher polydispersity in length and poor control on their sequence. Nevertheless, when they are used to permeabilize or break model liposome membranes, it is difficult to point to any clear advantage of peptide-based agents over synthetic copolymers. Subtle selectivity may emerge from application of these compounds onto more complex 
membranes, and specifically on cell membranes. The present mini-review is focused on reporting recent works that implemented polymer-controlled perturbation on the membranes of living cells, which is mostly achieved with non-blocky, amphiphilic copolymers including peptides and amphipol's relatives. Here we review recent and still emerging works, on synthetic polymers (i.e. abiotic) with brief parallel summaries of their commonalities with peptide tools that are actively developed nowadays. The first section illustrates promising applications of polymer-controlled functions of interest for biomedical purposes. The second section lists the variety of responses achieved on cell membranes, with emphasize on the parameters enabling to optimize their properties, specifically the molecular determinants of polymer translocation and formation of polymer-stabilized pores. Though it is certainly oversimplification, recent articles proposed interesting classification of polymers of various chemical natures on the basis of their hydrophobic/hydrophilic balance. This point of view guided development of stimuli-controlled modulation of the polarity or degree of ionization of polymer chains as a general route to achieve remote control on cell penetration or on toxicity, which is described in the last section of this review.

\section{Representative uses of copolymers to manipulate cells}

One recognizes nowadays three main domains of application involving polymers as disruptive agents, or modifiers of the cell membranes properties: encapsulation, biocides, and cell penetration. Coating of cells with macromolecules (that may reach condition of complete encapsulation) is generally sought to avoid contacts with immune systems or with deleterious interfaces. Biocidal and cell-penetrating agents are both macromolecules that bind membranes tightly, which in turn contributes to their internalization and/or formation of pores (Scheme 1). Below are summarized works that look promising for applied developments and that have in particular reached the stage of studies or implementation in vivo.

\section{Coating the cell periphery with polymers}

The various methods proposed in literature to attach polymers on the outer surface of living cells can be classified according to the nature of polymer interaction with the cell membrane, including: i) attachment of macromolecules, typically fluorescent ones for in vivo imaging of membrane proteins upon recognition of a polymer end-function (see (Relogio $\mathrm{P}$ et al. 2013)), or orthogonal covalent chemistry on recombinant substrates (see (Devaraj NK et al. 2012)); ii) adsorption of copolymer (adsorption often proceeds from hydrophobic 
anchoring of one or several hydrophobic moieties of the chain into lipid bilayers) (Guo ZJ et al. 1995), or with mammalian cells (Teramura Y et al. 2007), (Yook S et al. 2012)) ; or iii) electrostatic binding and assembly of polyelectrolytes multilayers onto the cell surface (Fakhrullin RF et al. 2012; Teramura Y et al. 2010). In the latter case, composite polymer layers are usually obtained on the basis of successive deposition of polymers of unlike ionic charges onto the cell surface (a method called "layer by layer" deposition, LbL). Non-toxic capsules made by similar techniques, and loaded with drugs, are promising carriers in pharmaceutical applications (De Koker S et al. 2012). As regard cell encapsulation, the earliest attempts used immobilized (and dead) human red blood cells (RBC) as well as Escherichia coli bacteria as sacrificial template for the elaboration of polymer hollow capsules (Neu B et al. 2001). Then living yeast cells were successfully encapsulated (into alternated layers of poly(allylamine hydrochloride) and poly(styrene sulfonate sodium salt)) (Diaspro A et al. 2002). The polyelectrolyte multilayers can be further functionalized with biomolecules for instance to improve Langerhans islets transplantation (Totani $\mathrm{T}$ et al. 2008) or doped by nanoparticles thereby enabling membrane labeling (application on fungi is reported (Fakhrullin RF et al. 2009)). An interesting application, showing that mild adhesion of LbL assemblies could be achieved, was developed on macrophages by Rubner et al. (Swiston AJ et al. 2008; Swiston AJ et al. 2010),(Doshi N et al. 2011). Macrophages were safely loaded with micrometer-large polyelectrolyte patches that form sorts of "backpacks" possibly containing drugs (Scheme 1). Cells bear such patches for days, which makes the cells an active "partners" for carrying and targeting therapeutics.

In general, polymer coats have been used to isolate cells from interaction with the external medium and specifically to escape the immune system, mostly for applications in cell or organ transplantation. Other yet marginal applications relate to tight adhesion onto tissue, for instance in intranasal delivery of vaccines (cationic nanogels carrying protein antibodies can stick to the nasal epithelium and are effectively taken up by mucosal dendritic cells) (Nochi T et al. 2010), encapsulation of biotechnologically relevant microorganisms such as bacteria (Franz B et al. 2010), or protection of mammalian cells in biosensors (e.g. MELN cell line used for estrogen detection (Germain M et al. 2006)). Lots of efforts were put on encapsulation, or surface modification, of pancreatic islets. To this aim, diffusion of small molecules, ions, and water must be preserved in the polymer layer(s), while the layer must represent a strong barrier against proteins with diameters above a few nanometers in diameter. Encapsulation can preserve cell viability, activity and in particular the capacity to release 
insulin upon glucose stimulation. The strategies listed below and illustrated in Scheme 1 have reached a significant degree of achievement: conjugation of PEG on the cell surface (Teramura Y et al. 2013), adsorption of amphiphilic polymer bearing alkyl side chains (Totani T et al. 2008), adsorption of lipid-conjugated poly(ethylene glycol) (Teramura Y et al. 2007),(Yook S et al. 2012), LbL encapsulation(Krol S et al. 2006; Wilson JT et al. 2011) or a combination of hydrophobic anchoring and LbL encapsulation (Miura S et al. 2006). Similarly, polymers were attached to red blood cells with the aim of screening interaction with plasma protein and producing a "universal" blood. PEG coupling (Scott MD et al. 1997) or LbL self assembly (alginate:lipid-modified chitosan (Mansouri S et al. 2011)) were successfully employed to mask antigens at the red blood cell surface and escape immunological rejection, while preserving the ability to carry oxygen. Finally, mesenchymal stem cells could also be encapsulated in a polyelectrolyte multilayer based on hyaluronic acid and poly(L-Lysine) that maintain cell viability (Veerabadran NG et al. 2007), (Garg P et al. 2012).

\section{Permeabilization of cell membranes, biocide activity}

In a context of persistence of incurable nosocomial infections by multi-resistant bacteria, it is desirable to search for new antibiotics, disinfectants, and antibacterial materials for usage in household, healthcare, functional textiles, and food packaging. A vast variety of polymers bearing cationic moieties, such as ammonium, guanidinium, sulfonium or phosphonium, are tailored to this end (for recent reviews on polymer biocides, see (MunozBonilla A et al. 2012; Siedenbiedel F et al. 2012), and on peptides (Futaki S et al. 2002), (Fillon YA et al. 2005) ). Molecular and spatial structures of polymeric biocides were initially inspired from cationic amphiphilic antimicrobial peptides (AMP, $c f$ infra) that are known since decades to facilitate pore opening in bacterial membranes. Not surprisingly, most synthetic copolymers that are lacking the well-defined sequence of AMPs, and do not fold into stable secondary structures, are typically less specific and of poorer efficiency than peptide biocides. Successful optimizations (cf infra) of these abiotic compounds were motivated by opportunities to produce them more economically and at larger scale compared to peptides. It is not yet possible to predict the exact properties of such molecules from their mere chemical structure. However, the general trends is a gradual variation of properties across a polymer series (e.g. upon increasing the density of hydrophobic groups in polymer chains), enabling one to maximize the bacterial killing activity, while avoiding toxicity on mammalian cells (in practice, author's checked either the absence of permeability of red 
blood cells, or day-long viability of mammalian cells in 2D cultures). Among parameters affecting biocide activity, recent studies illustrate the role of charge density/hydrophobicity ratio in random copolymers (e.g. statistic distribution of cationic and hydrophobic/philic units in polyacrylic derivative (Paslay LC et al. 2012), or poly(ethyleneimine) (He YC et al. 2012), or poly(oxetanes) (Chakrabarty S et al. 2011)) (cf Table 1 for the general structure of the poly(acrylic) backbones). The length of an hydrophobic spacer introduced between the cationic charge and the polymer backbone also affects efficiency (Palermo EF et al. 2012). The minimum inhibitory concentration (MIC) reached with optimal compounds, as low as 1-5 $\mu \mathrm{g} \cdot \mathrm{mL}^{-1}$, compares with 0.5-10 $\mu \mathrm{g} \cdot \mathrm{mL}^{-1}$ determined with AMPs (Chakrabarty $\mathrm{S}$ et al. 2011; Meng XT et al. 2012). There are even a few examples of antibacterial synthetic copolymers that display unexpected selectivity against Gram-negative vs Gram-positive bacteria, as for example poly(norbonene)-based compounds (Lienkamp K et al. 2009) and methacrylate copolymer with a pendant dodecyl-quaternized ammonium moiety (Dizman B et al. 2004).

In comparison, peptides biocides are generally not more selective than non-peptidic copolymers. Among membrane-interacting peptides, different classes have been described according to their intrinsic biological activity that include antimicrobial, anti-cancer or cell penetration. In this paragraph, we consider antimicrobial peptides. Such peptides are known since 70 years, and are generally based on sequences of less than 30 amino acids with a dominant cationic amphipathic pattern. Although examples of negatively charged peptides were reported (Paulmann M et al. 2012), membrane-active peptides are generally cationic (containing Lys and Arg residues) and also contain hydrophobic (Ala, Val, Leu, Ileu, Trp, Phe) amino acids, leading to the general assumption that electrostatic interactions represent a key step in the binding process of these peptides to biological membranes. A well-studied membrane-active peptide is melittin $\left(\mathrm{NH}_{2}\right.$-GIGAVLKVLTTGLPALISWIKRKRQQ$\mathrm{CONH}_{2}$ ), isolated from the bee venom. This peptide is active against Gram-positive and Gram-negative bacteria but it has also strong hemolytic activity against red blood cells. Melittin is an amphiphilic peptide with a hydrophobic amino-terminal domain [1-20] while the carboxy-terminal [21-26] region is hydrophilic and positively charged at biological $\mathrm{pH}$. Interestingly, taken separately, the two domains do not show any hemolytic activity, a result that highlights the requirement for a favorable hydrophobic:hydrophilic balance $(>1)$ in the amino acid content of the peptide, to induce membrane perturbation (DeGrado WF et al. 1982). Being water-soluble, melittin binds to negatively charged bacteria (Mollay C et al. 1976) and also zwiterionic eucaryote cell membrane phospholipids (Mollay C et al. 
1973),(Georghiou S et al. 1982). The positively charged melittin targets the membrane from the aqueous phase and partitions into zwitterionic phosphatidylcholine bilayers. It was shown that formation of nonpolar hydrophobic interactions between melittin and phospholipids represent a key step for the stabilization of the peptide/phospholipid complex. Magainin-2 $\left(\mathrm{NH}_{2}\right.$-GIGKFLKKAKKFGKAFVKILKK-CONH$\left.{ }_{2}\right)$ was isolated from amphibian skin (Zasloff M 2002) and is also a cationic and amphiphilic antimicrobial peptide, but with much less hemolytic activity than melittin (Unger T et al. 2001). By contrast with melittin, the two types of amino acids are not clustered within identified domains but are spread over the whole sequence of the peptide. In the case of magainin-2, binding and insertion of the peptide into the lipid bilayer is predominantly driven by electrostatic interactions (Wieprecht $\mathrm{T}$ et al. 1999). Thus, the two peptides, melittin and magainin-2 are characterized by an interfacial model of interaction with membranes that are representative of most of AMPs (Wimley WC 2010). Despite their similarity in terms of charges and non-polar amino acid content, the interfacial differences in the mode of action of melittin and magainin-2, clearly show that subtle interactions, conformational motion and kinetics should be accounted for to characterize the formation and the stabilization of peptide /phospholipid complexes. Sequence adjustment, variation of charge, hydrophobicity and amphiphilicity, and/or propensity to fold into helices have been studied on several antimicrobial peptides, and led to significant selectivity between Gram-negative and Gram-positive bacteria (Giangaspero A et al. 2001). Some antimicrobial peptides have also killing activity on cancer cells, in addition to their biocide action (Hoskin DW et al. 2008) [http://aps.unmc.edu/AP/main.php]. Their killing activity to bacteria or cancer cells may result from irreversible perturbation of the cell membrane integrity, or from intracellular targets of the peptides.(Riedl S et al. 2011) For instance the host defense-like lytic peptide ${ }^{-}$-K6L9 $\left(\mathrm{NH}_{2}\right.$-LKILKkLlkKLLkLL-CONH${ }_{2}$, where bold lowercase letters are D-amino acids) induces necrosis of tumor cells via a membrane depolarizing lytic process.(Papo $\mathrm{N}$ et al. 2006) Besides, buforin IIb (RAGLQFPVGRLLRRLLRRLLR) has been described as an anticancer histone H2A-derived peptide. Buforin IIb crosses without damage cancer cell membranes and induces mitochondria-dependent apoptosis (caspase 9 activation and cytochrome c release into the cytosol).(Lee HS et al. 2008)

\section{Cell-penetrating polymers}


Some water-soluble polymer chains are capable to bind to lipid membranes, and to turn after binding into a form that becomes solubilized in the hydrophobic interior of the lipid bilayers, and eventually translocates and penetrates into the cytosol. Cell-penetrating peptides, CPP, are known since 20 years, and can cross membranes within any cell type, without causing irreversible damage to the cell membrane (Milletti F 2012). On the other hand, completely abiotic macromolecules are also developed and have reached now penetration efficiencies that compare with CPP. Most of these CPP-mimics are cationic and contain both guanidine and hydrophobic side groups (Tsogas I et al. 2007),(Tezgel AO et al. 2011). But amphiphilic polyanions of various chemical structures have also been identified as cellpenetrating agents (Ho VHB et al. 2011; Torchilin VP 2012; Yessine MA et al. 2004). CPPs and abiotic penetrating polymers usually have no deleterious action inside cells, although some CPP can interact with cellular proteins such as actin (Delaroche D et al. 2010). An intriguing increase of phosphorylation (by I $\mathrm{B}$ kinases) upon penetration of abiotic polypropylene oxide together with specific sequences of DNA was however reported (Yang Z et al. 2008). Innovative drug delivery systems were based on cell-penetrating peptides (Koren E et al. 2012). The general therapeutic strategies implement CPPs or other polymers under the form of conjugated drug molecules that hopefully carry their load (oligonucleotides, DNA, SiRNA, peptide, protein, contrast agents, drugs) into the cytosol. Covalent attachment to CPPs includes disulfide, amide, thiazolidin bonds (Zorko M et al. 2005). Alternatively, non covalent complex assemblies are formulated to contain both CPPs and the drug or polynucleotides of interest (Deshayes S et al. 2012),(Crombez L et al. 2009),(Andaloussi SE et al. 2011). With abiotic polymers, applications macromolecular agents are at an earlier stage of development, although amphiphilic polyanions are promising $\mathrm{pH}$-triggered systems (Yessine MA et al. 2007). Note that we refer here to molecular penetration, and not to the vast field of nanoparticles formulation that has reached a remarkable importance in pharmaceutical sciences and in studies of cell transfection. Those drug, or DNA, cargoes (often polymer micelles, capsules, or colloid particles) are basically tailored to optimize drug loading, enhance the blood circulation time, and to protect drugs from degradation in endosomes. Cell penetration of such polymeric particles may however significantly differ from a molecular translocation, and for instance could proceed from active endocytosis and natural permeability of the endosomal membrane to the drug of interest (Hu XL et al. 2009; Nicolas J et al. 2013). In the case of diblock copolymers containing one cationic and one neutral (typically poly(ethyleneoxide)) block, stabilization of pores in lipid membrane by the polymer chain may however contribute to the efficiency of transfection. (Huin $\mathrm{C}$ et al. 2011) 
Although numerous CPPs are positively charged, the amino acid composition, and sequence polarity, or hydrophobicity of these peptides is broadly defined (http://crdd.osdd.net/raghava/cppsite/index.php) and a general rule for identifying efficient sequences is lacking. In addition, complex sensitivity to environment is at play. For instance the anionic (and amphiphilic) peptides called pHLIP enables tumor targeting thanks to their abrupt solubility transition near physiological $\mathrm{pH}$ that triggers penetration into mammalian cells upon a local $\mathrm{pH}$ variation of less than $0.5 \mathrm{pH}$ units (Andreev OA et al. 2010; Weerakkody D et al. 2013). The most used cell-penetrating peptides are Tat (GRKKRRQRRRPQ, derived from the transcription transactivator of (TAT) the human immunodeficiency virus, (Vives E et al. 1997)), Penetratin (RQIKIWFQNRRMKWKK, derived from the Antennapedia homeodomain of drosophila (Derossi D et al. 1994)), and oligoarginine (Rn, designed peptides, (Mitchell DJ et al. 2000),(Futaki S et al. 2001)). These peptides deliver different types of cargoes into cells or in vivo (Koren E et al. 2012),(Nakase I et al. 2012a). For instance, doxorubicin conjugated to Tat or Penetratin induces apoptosis of human breast cancer cells (Aroui S et al. 2009), or leads to tumor growth suppression (Nakase I et al. 2012b). Topical uptake of Cyclosporin A is enhanced when the molecule is conjugated to $\mathrm{R} 7$ peptide, and results in the inhibition of dermatitis inflammation process (Rothbard JB et al. 2000).

\section{Controlling the interaction with cell membranes, from mild attachment to poration and permeabilization.}

To identify the relevant molecular determinants, i.e. parameters that play a role in polymer:membrane interaction, a common strategy consists in optimization of the chemical structure of polymers. For example, varying the composition of polymer chains that contain two or more different functional groups affords gradual variations of properties, and is readily achieved by controlled synthesis. Typical studies investigated the relationship between cellbinding propensity (or toxicity) and the density of a particular side group in linear segments of the chains (e.g. ammonium, guanidinium, aromatic, n-alkyl side groups, etc). Alternatively, the cell responses (including cell death) to variation of the composition of polymers provided indirect indications of the importance of hydrophobicity, charge, or hydrogen bonds. Additional and experimentally accessible determinants include i/ steric repulsion that hampers binding (e.g. upon introducing large repulsive polyethyleneglycol, PEG, (Stratton TR et al. 2011)), ii/ spatial distribution of functional groups (e.g. upon variation of the architecture of 
branched chains, or dendrimers), and iii/ chain length. The main conclusions drawn from these studies are summarized for abiotic polymers in the section IIa. Obviously in the case of peptides, similar approaches can focus on specific effects of sequences, and stereochemistry of amino acids. This case is briefly discussed in part IIb. Finally, and not surprisingly, polarity (or hydrophobicity) of segments in the polymers is a recognized criterion that deserves attention. In section IIc, we present both experimental studies and modelization of hydrophobically-driven penetration of chains inside bilayers. This last section illustrates also how the simplicity of a rational based on hydrophobic/hydrophilic balance has in practice been exploited to achieve on/off control on perturbations of cell membranes upon stimulitriggered switch of responsive chains.

\section{II.a Synthetic copolymers}

Due to the exploration with synthetic polymers of a variety of monomers having very different chemical natures, results obtained with synthetic chains should help to identify the main determinants of the function of interest. In practice, adsorption, penetration or biocide activities were obtained with either neutral, anionic, or cationic polymers, and with polymer chains containing different amount of hydrophobic groups, either aliphatic or aromatic. There is accordingly no specific chemical group associated with one class of behavior. The essential feature in all optimization strategies of copolymers is rather the combination of typically two monomer "units" of unlike polarity/hydrophilicity, namely a water-soluble unit and one unit prone to associate with lipids (e.g. anionic with hydrophobic, or cationic with neutral/hydrophilic). Within a set of homologous macromolecules, the gradual variation of the fraction of the two "units" modulates gradually the interaction with membranes, which makes properties of polymers to evolve from weak and reversible adsorption, toward tight and longlasting adsorption (as used in coating application), penetration, selective-biocide and finally non-selective biocide activity. Although exploration of the full window of properties listed above was usually not assessed for each set of copolymers, the correlation between higher density of cationic, or hydrophobic moieties, and tighter association is generally obeyed. It has been validated for the somewhat heterogeneous list of compounds commented in the following paragraphs (see illustrations of structures in Table 1a).

\section{II.a.1. Hydrophobic/hydrophilic balance}

As regards hydrophobically-modified neutral chains, pullulan adhesion (Guo ZJ et al. 1995), or endocytosis of pullulan cationic derivatives (Ayame $\mathrm{H}$ et al. 2008)) were 
strengthened by increased degree of hydrophobic modification. Similarly, tissue adhesion could be enhanced upon increasing the degree of hydrophobic side groups in gelatin-based glues (Matsuda M et al. 2012). End-functionalized PEGs containing lipid(s) at their chain end(s) also showed obvious strengthening of binding, while turning from mono- to difunctional chains. Monofunctional chains are rapidly removed/desorbed from the cell surface, with no uptake in the cytoplasm, when cells are subjected to dilution or washing steps (Teramura Y et al. 2008). But PEG with two oleyl ends may act somewhat cooperatively to stably agglomerate dilution-resistant cell-spheroids (Ito M et al. 2009),(Rao Z et al. 2013). Moreover, if the polymers carry several hydrophobic anchors, the binding appeared significantly more stable: Teramura and coll. (Teramura Y et al. 2008) randomly grafted (neutral) poly(vinyl alcohol) copolymer carrying multiple n-alkyl side groups (PVA-alkyl) that tightly adsorb on the whole surface of cells, at short time after supplementation of the cell culture medium with the polymer. Despite removal of the excess unbound chains by washing, PVA-alkyl was slowly gathered into patches on cell surface, or was taken up into the cytoplasm (Teramura Y et al. 2008). Anionic copolymers obey similar trends as the neutral ones. Yessine et al. showed the increase of the efficacy toward membrane breakage, and sp. endosome escape, with increasing hydrophobicity of poly(glycolic acid-co-octadecylacrylate) (Yessine MA et al. 2004), or alkyl-modified poly(ethylacrylate) (Chen T et al. 2004) (Table 1a). Stayton et al. did similar studies on poly(styrene-co-maleic acid) derivatives (Henry SM et al. 2006). Studies in Ronjung Chen's group showed that poly(acrylamide) derivatives (namely poly(Lysine)-phtalamide) bearing amino-acide pendant groups obeyed the same rule in that hydrophobicity (due to phenylalanine grafts) brought better penetration in cell spheroids (Ho VHB et al. 2011) (Khormaee S et al. 2013), or more pronounced perturbation of model lipid layers (Zhang SW et al. 2011). Ishihara and coll. similarly tailored the hydrophobicity of polymeric derivatives of phospholipids to achieve control on cell penetration, here for fluorescent labeling (Goda T et al. 2010; Ukawa M et al. 2010). Finally, the larger range of hydrophobicity studied on homologous model systems was presented in the work by C. Ladaviere, F. Vial et al. that increased the degree of random n-alkyl grafting (octyl or dodecyl groups) on poly(acrylic) chains. These copolymers added to liposome solutions affected properties of the liposomes by i/ dilution-resistant attachment of chains containing a few mol\% hydrophobes, ii/ permeabilization and stabilization of nanometer large pores with more hydrophobic chains, iii/ membrane disruption upon increasing further their hydrophobicity by either decreasing $\mathrm{pH}$, or decreasing the charge density of the copolymers. In practice, the authors achieved controlled formation of lipid lateral domains in egg-PC 
bilayers (Ladaviere C et al. 2002), membrane buddings, poration (Vial F et al. 2007), and lipid solubilization into polymer mixed micelles (Vial F et al. 2009; Vial F et al. 2005).

\section{II.a.2. Effect of cationicity}

We turn now to cationic chains that adhere to negatively charged cell surfaces by coulombic attraction, irrespective of the presence of other functional groups such as hydrophobic ones. Here, due to a lack of clear identification of the mechanism of binding, the term coulombic attraction gather all observed trends toward association of polyelectrolytes with membranes of unlike ionic charge, that may include electrostatic effects and entropic ones (release of counter-ions) Exposure of cell surface to polycations raises problems of toxicity. The cytotoxicity of polycationic macromolecules is influenced by different properties of the polymer such as molecular weight, charge density and nature, and macromolecular chain flexibility (Munoz-Bonilla A et al. 2012), (Fischer D et al. 2003), (Chanana $\mathrm{M}$ et al. 2005). With synthetic polycations commonly used in transfection studies (poly(ethylenimine), poly(L-lysine), poly(diallyl-dimethyl-ammonium chloride), diethylaminoethyl-dextran, poly (vinyl pyridinium bromide)) higher molecular weight and higher charge density induce higher toxicity on mammalian cells. Similar effect exists with natural chains, as longer aminoethyl-modified chitosan show enhanced porogenicity and biocide activity compared to its shorter relatives (Meng XT et al. 2012). But this simple trend may not be valid for antimicrobial activity. It has been suggested that molecular weight affects selectivity of antimicrobial amphiphilic polycations for Gram-positive vs Gramnegative bacteria (Lienkamp K et al. 2008), and that increasing chain length may decrease activity against $\mathrm{S}$. Aureus because long macromolecules are better trapped in the negatively charged murein layer of this bacteria. Thus generalization from toxicity studies must be considered with caution. Higher rigidity decreases the cytotoxicity (presumably because rigid macromolecules encounter difficulties to fully adsorb into the cell membrane) (Chanana $\mathrm{M}$ et al. 2005). Among the most studied cationic polymers, Poly(ethylene imine) (PEI) and poly(LLysine) (PLL) display the highest charge density and thus are the most toxic polycations (N.B. dendrimers may also reach higher charge densities than PEI). But the toxicity of PLL can be modulated by the composition of the buffer, during the cell-coating process. Cell viability was accordingly preserved in the presence of $\mathrm{K}+$ in the buffer, which enabled reduced interaction between polyelectrolytes in LbL capsule preparation. In this case, incomplete encapsulation could be the origin of the higher cell survival rate (Germain M et al. 2006). With the aim of full encapsulation of cells in LbL (which requires preparation of a first 
homogenous cationic layer around the cells), one way to reduce toxicity is to reduce accessibility of cations upon grafting cell-repellant poly(ethylene glycol) (PEG) chains on the amine groups, or elsewhere in the polycation chain (Mansouri S et al. 2011; Wilson JT et al. 2011). In model liposomes, sterically-controlled formation of lateral domains of (anionic) lipids were convincing proof of possible balance of coulombic attraction by PEG-PEG repulsion (Pashkovskaya AA et al. 2006). In cell cultures, however, the exact role of steric hindrance is not understood. Variation of the fraction of primary amines (vs secondary and tertiary ones) should be considered, and is clearly involved in biocide activity (Paslay LC et al. 2012). It has been shown that primary amines enhance complexation with the phosphate groups of lipids and increase bilayer's permeability (Palermo EF et al. 2011). Molecular modeling highlighted in addition a possible change in conformation of polycations upon increasing the degree of grafting of PEG. Starting from a extended coil, the chain containing higher PEG density turns into a more compact globular structure(Wilson JT et al. 2011) which may explain a lower accessibility of its charges, and thus lower toxicity (Fischer D et al. 2003; Hong SP et al. 2006). In practice, the grafting ratio of PEG can be optimized to decrease markedly toxicity while preserving the ability to bind on cells, thus such chains are good precursor for encapsulation by LbL methods. Whereas the remarks above apply also to guanidinium-containing polymers, the peculiar properties of this cationic group are now clearly identified (Cooley CB et al. 2009; Hennig A et al. 2008; Holowka EP et al. 2007; Mattheis C et al. 2013; Tezgel AO et al. 2011). Guanidinylation of polymer chains speeds up cytotoxicity, and affords better penetration of highly hydrophilic polymers in cells by energyindependent pathways. Enhanced penetration compared to macromolecules bearing amine groups presumably comes from the ability of guanidine group to form hydrogen bonds with phosphate ions, stabilizing complexes with phospholipids (Rothbard JB et al. 2004; Rothbard JB et al. 2005), and references in (Tribet C et al. 2008). Accordingly, guanidinium-containing copolymers are promising carriers for cytosol delivery of small molecules with high water solubility (due to their high charge density), and high efficiencies modulated by competitive interaction with anionic counterions, such as ATP or heparin (Hennig A et al. 2008).

\section{II.a.3. Amphiphilic polycations}

Finally as for neutral or anionic chains, the introduction of hydrophobicity in polycations reinforces their propensity to bind and penetrate lipid membranes. In its fruitful quest for synthetic mimics of antimicrobial peptides, the group of Kenichi Kuroda has published systematic studies of the variation of structural parameters of polycations (Palermo 
EF et al. 2009b) (Kuroda K et al. 2009). Although the mechanism of antimicrobial activity is debated, and may differ significantly from a simple permeabilization (Sovadinova I et al. 2011b), exponential decrease with linear incorporation of hydrophobic monomers in the chains of both minimum inhibitory concentration and HC50 (concentration of half hemolysis of red blood cells) clearly confirmed the importance of hydrophobic moieties. It is interesting to note that the distribution of hydrophobes in the polymer chains affected hemolysis more than antimicrobial activity. Dibloc copolymers (one hydrophobic and one hydrophilic bloc) had similar biocide activity as random ones (containing the same monomers in similar amount per chain), but essentially no hemolytic activity (Oda Y et al. 2011). Authors suggest that because dibloc copolymers come into solution under the form of stable micelles, with all cationic groups pointing in the periphery of the hydrophobic core, they may essentially bind to cell by coulombic interaction (they can trigger hemagglutination). In contrast, random copolymers were bound by both coulombic and hydrophobic interaction, which renders these polymers more hemolytic. A different family of chains has been developed by G. Tew and coll. Based on original poly(oxanorbornene) derivatives, with one or two pendant group(s) per repeat unit to modulate both hydrophobic and cationic densities (Hennig A et al. 2008; Lienkamp K et al. 2009; Lienkamp K et al. 2008; Som A et al. 2012; Tezgel AO et al. 2011). These polymers obeyed the same rules as the acrylic derivatives discussed above, in that increasing the density of a given hydrophobic side group improved biocide activity, and finally turned the polymers into hemolytic (non-specific cell permeabilizers). These trends were correlated with permeabilization of model lipid vesicles, confirming that the affinity for lipids plays a major role (Gabriel GJ et al. 2008). Interestingly, the role of the aliphatic or aryl nature of hydrophobic side groups were compared on the basis of their biocide efficiency, and apparent hydrophobicities (as determined by reverse phase chromatography) (Som A et al. 2012). It appeared somewhat surprisingly that transduction activity was not solely dominated by hydrophobicity, but rather that aromaticity played a crucial role. Despite a markedly lower retention of the corresponding monomer on reverse-phase chromatography, phenyl-modified polymers showed significantly higher activity than aliphatic-modified macromolecules of comparable size (i.e. when both monomers were carrying hydrophobic side groups with the same number of carbon atoms), and inverse correlation with hydrophobicity and biocide activity were observed in a set of polymers modified with aromatic side groups (Som A et al. 2012). Tew and colleagues Also report observation of an optimal length for n-alkyl side groups that presumably betrayed a contribution of intra-chain hydrophobic collapse (polymers 
containing high densities of long alkyl groups may prefer to form micelle-like globules remaining in water) (Lienkamp et al., 2008).

\section{II.b. Structure-properties relationship for peptides}

\section{II.b.1.The predominant role of composition}

Linear membrane-active peptides are generally unstructured in water solution, and adopt secondary structure when they bind to membranes. Various secondary structures ( $\alpha$-helical, $\beta$-sheet, cyclic, globular, random coil) have been described for both antimicrobial and cellpenetrating peptides. Studies of antimicrobial and cell-penetrating peptides show that there are no preferred secondary structures that correlate with their membrane activity. It is also important to note that the folding state adopted on the membrane depends on peptide concentration or peptide/lipid ratio, a property that confers to some membrane-active peptides a chameleon-like behaviour. For example Penetratin adopts an $\alpha$-helical structure at low peptide:lipid ratio and shifts to a $\beta$-sheet with increasing density (Magzoub M et al. 2002). These different conformations of penetratin could be observed also in cells (Ye J et al. 2010).

The nature of amino-acid (ionic, hydrophobic, polar) in the primary sequence appears more important than secondary structure to explain the effect of peptides on membrane organization. Whatever the class of peptides with antimicrobial, anticancer or cell-penetration activity, their sequence typically contains cationic and hydrophobic residues (with a few exceptions such as Glu- and Asp-rich, pHLIP (Andreev OA et al. 2010; Weerakkody D et al. 2013) or Dermcidin peptides that are anionic). Positively charged peptides interact with bacteria or mammalian cells by electrostatic and hydrophobic association, at least at the onset of binding. For mammalian cells, peptides have to diffuse through the glycocalyx in the extracellular matrix. In this context, multiple routes of entry of CPPs have been described, that include active endocytic pathways (clathrin-dependent, caveolin-dependent, macropinocytosis) and temperature-independent translocation. The question of the peptide release from intracellular endocytic vesicles has been extensively studied within the last years and endosomolytic activity (escape from endosomes at acidic $\mathrm{pH}$ ) of cell-penetrating peptides have been correlated with hydrophobicity (Madani F et al. 2013). Coulombic effects are also involved in targeting lethal activity of peptides against cancer compared to non-cancer mammalian cells. As a result of the multiple modifications of cancer cells, the outer membrane leaflet of cancer cells displays excess anionic phosphatidylserine and/or of glycosylated species such as sialic acid or heparan sulfate, and have a more negative 
membrane potential, a more acidic $\mathrm{pH}$ in the cell environment (Riedl S et al. 2011),(Harris F et al. 2013). It appears that cell killing by AMP through necrosis (cell membrane lysis) or apoptosis (lysis of mitochondria) both depend on the presence of anionic lipids in the outer leaflet of the membrane bilayer. A similar importance of surface charge is valid for cellpenetrating peptides (CPP). At the cell-surface, these peptides interact first with negatively charged glycosaminoglycans. These proteoglycans are possible portals for entry into cells. The influence of GAGs on the entry was shown qualitatively,(Suzuki T et al. 2002),(Console S et al. 2003),(Poon GMK et al. 2007) and could be measured quantitatively (Jiao CY et al. 2009),(Alves ID et al. 2011a),(Walrant A et al. 2011),(Bode SA et al. 2012), (Bechara C et al. 2013). In the absence of glycocalix, simulations show that hydrogen-bonds and anion-cation pairing between the bilayer and arginines or lysines are the key determinants of the association of penetratin (Pourmousa M et al. 2013). In addition, tryptophans but not phenylalanine makes hydrogen-bonds with the phosphate group of lipids (Pourmousa M et al. 2013). These results are in good agreement with experimental observation of [W48 $\rightarrow \mathrm{F}$ ] Penetratin mutant entering less in cells than their parent peptide (Derossi D et al. 1994). Charge-pair interactions and hydrogen bonds are also crucial in the cell-penetrating properties of oligoarginine sequences. In this case, guanidinium moieties form bidentate hydrogen-bonds with the phosphate groups of phospholipids, and makes the peptide capable to partition in the membrane bilayer and migrate to the inner leaflet, along with the membrane potential (Rothbard JB et al. 2004). Of major interest is a recent work by Nakase and collaborators (Nakase I et al. 2012c), who report the transformation of an antimicrobial peptide into a plasma-membrane permeable one. In this study, all lysyl residues of the KLA antimicrobial peptide (KLAKLAKKLAKLAK) were replaced by arginine, and the peptide shows no longer antimicrobial activity but gains cell-penetration properties and can accumulate into mitochondria. This result highlights the importance and the contribution of guanidinium side chains in the fine tuning of membrane-active peptide activity.

\section{II.b.2.Role of hydrophobicity on peptide penetration in the membrane.}

Kinetics and thermodynamics of binding of all membrane-active peptides are crucial parameters to understand how peptides reversibly or irreversibly perturb the organization of biological membranes. In this regard, lessons from the antimicrobial peptides, are important guides for the whole field of membrane-active peptides. A striking example is provided by a kinetic and thermodynamic study on Melittin, a peptide that is known to form pores in 
zwitterionic membranes and on Magainin that does not, although the two peptide sequences are similar in their amino acid composition (Papo $\mathrm{N}$ et al. 2003). Electrostatic interactions may or not govern the initial step of the peptide binding to the membrane. For instance, the rate of association of Magainin is increased $(\approx 10$-fold $)$ while the rate of dissociation is decreased $(\approx 10$-fold) when the peptide binds anionic lipids compared to zwitterionic ones. Once bound, insertion kinetics of Magainin within the hydrophobic core or into the inner surface of the bilayer is similar with anionic and zwitterionic bilayers, indicating that this second step is no longer driven by electrostatics (Papo N et al. 2003). In addition, Magainin has little preference for anionic bilayers compared to monolayers, a point that has been interpreted as a hint of predominant parallel adsorption on the membrane surface (Bechinger B et al. 1993). Uncomplete insertion of Magainin into anionic bilayers advocates for a translocation requiring the presence of pores rather than the direct crossing of individual, membrane-soluble peptides (Matsuzaki K et al. 1995). Formation of pores is also in line with antibacterial activity. By contrast, Melittin binds with similar association and dissociation rates onto anionic and zwiterrionic bilayers (Papo $\mathrm{N}$ et al. 2003). In the case of zwitterionic lipids, the peptide has much higher affinity for bilayers than monolayers, suggesting a deep insertion. These results suggest that hydrophobic interactions are involved in Melittin / membrane binding (Vogel H et al. 1986). Melittin induces pore formation in zwitterionic membranes and has detergent-like properties in anionic membranes and hemolytic and bactericide effects (Ladokhin AS et al. 2001).

As for antimicrobial peptides, membrane models have been proposed to understand how cell-penetrating peptides interact with the lipid bilayer and the main ones are illustrated below. Penetratin (RQIKIWFQNRRMKWKK) does not bind to specific phospholipids, since the same partition constant was measured, irrespective of anionic/zwitterionic lipid ratio (Persson D et al. 2004). Penetratin interacts and lies parallel with the surface of the lipid bilayer (Magzoub M et al. 2002), while tryptophans are not well buried into the bilayer core (Berlose JP et al. 1996),(Christiaens B et al. 2002),(Brattwall CE et al. 2003). Similarly Tat peptide (GRKKRRQRRRPQ) cannot insert into the hydrophobic bilayer, and the peptide binds at the membrane surface via electrostatic interactions, just tight enough to change the conformation of anionic phospholipid polar heads (Ziegler A et al. 2003). Other cellpenetrating peptides, including R9 (RRRRRRRRR), RW9 (RRWWRRWRR) and RL9 (RRLLRRLRR), behave differently. RW9 and R9 have high efficiency to enter into cells, while RL9 is poorly internalized, a rather striking observation since the replacement of Trp with Leu led to a peptide of higher hydrophobicity (Walrant A et al. 2011). RW9 and R9 have 
similar interactions with anionic phospholipids. They destabilize the gel phase state of the lipid bilayer, affect the packing of the fatty acid chains and insert loosely into the hydrophobic core of anionic membranes, while RL9 inserts deeper but does not affect the packing of the acyl chains (Walrant A et al. 2011),(Walrant A et al. 2012). In addition, R9 and RW9 can influence the membrane curvature while RL9 does not. Thus, it appears from these few examples of cell-penetrating peptides, that a deep insertion/hydrophobic binding in the membrane bilayer is not always required for translocation of the peptides. Although all these membrane-active peptides look similar in terms of their physico-chemical properties, they clearly have a finely tuned mode of interaction with, and action on the membrane.

II.c. Controlling the degree of polymer insertion in membranes: a basic principle of stimuliresponsive systems.

At supramolecular scales, the effect produced by polymers on properties of lipid membranes can be described by variation of membrane's equilibrium curvature, of bending moduli, of partition or binding constants of macromolecules, of lipid ordering or in other terms shift in lipid phase transition. Irrespective of the chemical class of membrane-active polymers, these parameters govern the stability of membranes. Except for cases involving peptide self-organization into well-defined assemblies, it is thus not surprising that the models of perturbation by either peptides or abiotic amphiphilic chains share many similarities. The reader is referred to reviews that recall well-known models of polymer insertion in bilayers and porogenicity ((Binder WH 2008) and (Alves ID et al. 2011b), and Scheme 2). As regard permeabilization, or translocation mechanisms, peptides have been the purpose of significantly more studies than abiotic macromolecules. The recognized effects of peptides on membrane properties are briefly recalled in the following. Citations of available results on abiotic chains are also inserted in this paragraph, when tentative mechanisms could be proposed in conditions similar to that established with peptides. A well-accepted view is that at low concentration, an antimicrobial peptide binds to the membrane, modifies lipid organization and alters membrane structure. Upon increasing AMP concentration and lipophilicity, a breakpoint is reached, that enables translocation. Above a threshold concentration in the bilayer (peptide:lipid of ca. 1:500 to 1:50 mol/mol), AMPs become membrane-disruptive (Nguyen LT et al. 2011). Similar concentration and affinity threshold are reported for cationic abiotic biocides (see above). Several structures of pores were suggested for AMPs (Scheme 2): the barrel-stave model proposes that a pore is formed with 
peptides standing parallel with one another to form the inner "wall" of the pore. In toroidalpores, no specific peptide-peptide alignment is required. Instead, peptides modify the local curvature in a cooperative manner, which locally stabilizes highly curved, peptide-rich, toroidal shapes. Other models suggest that peptides become antimicrobial when they can "carpet" the lipid surface, which results as for detergents in gradual enhancement of the propensity to form highly curved structures. These three models have obviously inspired the mechanisms (not yet fully validated) proposed in the case of abiotic chains, devoid of secondary structures (Binder WH 2008), (Tribet C et al. 2008). Note that an individual AMP may "utilize" different mechanisms depending on the experimental conditions. Studies suggested that Melittin forms transmembrane pores in zwitterionic lipid bilayers via a barrelstave mechanism (Vogel $\mathrm{H}$ et al. 1986) but acts as a detergent in negatively charged membranes (Ladokhin AS et al. 2001). AMPs were splitted into two classes depending on their mechanism of action being pore-dependent or pore-independent. As recently pointed out, all membrane-active peptides should however be seen as a single family (Bechinger B et al. 2012b), since the early classification was essentially based upon the biological functions, and did not consider gradual variation of interaction with biological membranes. One attractive model is that all peptides may be ranked on a common scale depending on the perturbation energy achieved on membrane bilayers (Last NB et al. 2013). First, upon simple adsorption, this perturbation comes from the lateral tension induced on the membrane, due for instance to the fact that peptide binding causes changes in the packing of polar head groups and acyl chains of lipids. Lateral tension increases the frequency of occurrence of membrane thinning, and/or formation of defects decreasing the energy of pores (N.B.: tension is released by opening a pore). Second, membrane-active peptides could recruit and cluster specific membrane lipids (Scheme 2), and thus locally evokes membrane thinning and defects. The intrinsic kinetics to partition between surface and defect regions would represent fundamental physico-chemical mechanism controlling the biological activity (cytotoxicity, translocation).

Presumably because abiotic chains generally lack the capacity to form well-organized, rigid structures, it is generally assume in this case a more direct correlation between the propensity of polymer segments to associate with lipids and membrane penetration, or translocation. This point of view found recent experimental validation in vitro, on model liposomes with non-ionic chains (Yaroslavov AA et al. 2006) (Demina T et al. 2005), or cationic polymers on monolayers studied by X-ray scattering (Hu K et al. 2013). Recent Monte Carlo simulation of homopolymer:bilayer association show that there is an adsorption 
transition at a threshold polarity of the chain. Close to this threshold both the translocation probability and the permeability of the membrane with respect to solvent are enhanced (Werner $\mathrm{M}$ et al. 2012). In another molecular dynamic simulation of a cationic poly(amphiphile), Palermo et al. showed that the chain backbone can be anchored flat in the subsurface of lipid bilayers upon increasing monomer's hydrophobicity (Palermo EF et al. 2012). Flat conformation of adsorbed chains and orthogonal penetration of $n$-akyl side groups in the lipids was experimentally validated on lipid monolayers by advanced interfacial spectrophotometry (Avery CW et al. 2011). Finally, comparison of the membrane curvature induction, and variation of phase transition diagrams of lipids upon adsorption of abiotic or peptidic antimicrobial compounds (Ishitsuka Y et al. 2006) also suggests that these chemically remote macromolecules may be closer than expected from the point of view of membrane energetics. To finally present an homogenous sketch of the field, it is interesting to compare polymers of different chemical structures on an hydrophobicity scale (Figure $1 \mathrm{CHu}$ $\mathrm{K}$ et al. 2013) and refs therein). Hu et al. averaged water-octanol partition, LogP, of the constitutive monomers of antimicrobial lysine-rich peptides, or cationic derivatives of poly(acrylate), in order to plot resulting values (N.B. sequence-independant averages) as the $\mathrm{X}$-axis in a diagram ranking efficient biocides. Synthetic random copolymers appear in Figure 1 to be of similar or slightly higher hydrophobicity in general than macromolecules in the peptide family. In contrast, poly(acrylate) chains were found significantly more cationic, with an average charge densities up to four time that of peptides of similar efficiency. Obviously, charge-charge repulsion occurred in flexible random copolymers has a marked impact on chain extension, that in turn may hamper hydrophobic collapse and penetration in lipid layers. Suitable pre-orientation of charged moieties, e.g. facial distribution, due to folding of peptides may be responsible of this large apparent shift. It is important to note however that the averaging, not only masks details about important contribution of sequences, but even for random copolymers, does not properly reflect the accessibility of side groups of the polymers. For example, increasing hydrophobicity should favor self-assemblies of amphiphilic chains into micelle-like globules, as for Amphipols. Though systematic studies are missing, it seems that self-assemblies represent another threshold for polymer:lipid interaction: in the case of cationic derivatives, non-monotonous variation of biocide (and hemolytic) efficiencies with increasing hydrophobicity was tentatively ascribed to formation of highly hydrophilic globules with cationic groups in their outer shell (Kuroda K et al. 2009) (Sovadinova I et al. 2011a). In a somehow opposite observation, micellar assemblies of polyanionic amphiphiles, belonging to the family of Amphipols, were shown to solubilize lipid vesicles, whereas 
relatives of lower hydrophobicity could not and were only adsorbed in the bilayers (Ladaviere C et al. 2002; Vial F et al. 2009).

Of practical interest, the recognition of critical switch by the charge/hydrophobicity ratio enabled the design of polymers affording the remote control of membrane destabilization (or permeabilization) with stimuli-responsive macromolecules. These macromolecules contain hydrophobic anchors to bind to the membranes and most importantly are close to poor solvent conditions. A wide variety of stimuli-responsive macromolecular structures have been tested in liposome formulations, under the form of amphiphilic copolymers (Yessine MA et al. 2004), (Pack DW et al. 2005), (Hoffman AS et al. 2002). The membrane breakage is generally obtained near a threshold $\mathrm{pH}$ or temperature conditions that make the polymer to abruptly undergo a transition from water-soluble into water-insoluble coil-globule conformation (Yessine MA et al. 2004),(Roux E et al. 2003). Typically, polymers containing carboxylic acids side groups are hydrophilic at high $\mathrm{pH}(>7)$ under their polyanionic form (cf Table 1b), but turn into water-insoluble globules when $\mathrm{pH}$ is decreased below the $\mathrm{pKa}$ of the monomer units (typically 5.5-6.5, or in vivo at the $\mathrm{pH}$ of late endosomes). These polymers become abruptly insoluble upon neutralization (Yessine MA et al. 2004),(Thomas JL et al. 1996),(Chen $\mathrm{T}$ et al. 2004). Amphipol A8-35 and A8-75 belong to the family of $\mathrm{pH}-$ responsive polyanions. Our results indicate that A8-75 is typically a $\mathrm{pH}$-dependant cell permeabilizer, whereas the more hydrophobic A8-35 slowly solubilizes lipids and breaks membranes at acidic pH (Vial F et al. 2009; Vial F et al. 2007; Vial F et al. 2005). On the other hand, temperature-responsive polymers have been tailored to trigger bilayer permeability above a threshold temperature. Such systems are based on solubility transition of N-isopropylacrylamide units (Ringsdorf H et al. 1993) (Kim JC et al. 2002), propylene oxide units (Chandaroy $\mathrm{P}$ et al. 2002) (Firestone MA et al. 2005), or organophosphazene (Couffin-Hoarau AC et al. 2004). In all cases, the monomers become less hydrated at temperatures above $35-40{ }^{\circ} \mathrm{C}$ (i.e. the lower critical solubility temperature, LCST, of the chains). Finally, light is a clean, versatile trigger that enables spatial and temporal control. To date only one example of biocompatible light-responsive polymer permeabilizer has been published (Sebai S et al. 2010; Sebai SC et al. 2012) (Figure 2 and Table 1b). But other photosystems exist (they are yet toxic or not efficient in cell culture condition). Biocompatibility issues have motivated the development of stimuli-responsive polymers of diverse chemical structures, in order to optimize responses in serum (Francis MF et al. 2001) for cell agglomeration (Iwasaki Y et al. 2013) permeabilization of mammalian cells, or 
biocide activity (see Figure 2 for illustrations on T-responsive and light-responsive polymers, or for pH-triggered ones: (Henry SM et al. 2006),(Lackey CA et al. 1999),(Eccleston ME et al. 2000),(Kusonwiriyawong C et al. 2003)). The exact origin of stimuli-controlled membrane disruption is to date largely conjectural. It is likely that insoluble segments of the chains penetrate inside the bilayers and introduce defects in their organization by a deep inclusion of ethoxy or carboxy groups in the apolar lipid core (Ferri JK et al. 2005),(Ringsdorf H et al. 1993). In addition, polymers forming micelles in water are presumably capable of stabilizing the rim of fragments of lipid bilayers with local curvatures below 3-4 nm.

\section{Conclusion}

Recent experiments implemented synthetic copolymers in cell cultures and evidenced that abiotic macromolecules are interesting substitutes of peptides for controlled cell permeabilization, or biocide activity. On the other hand, mild polymer coats were tailored to prepare "decorated" cells that escape recognition by the immune systems, or are imparted with better resistance to external stress. There are several motivations to use macromolecules as tools to manipulate the membrane of cell (Teramura Y et al. 2010). First, macromolecular systems facilitate a combinatorial approach, connecting several functions and independent regions in polymer chains (or assemblies) in order to target, carry, and deliver activation or contrast agents at specific location (Shokeen M et al. 2011),(Relogio P et al. 2013). Second, the properties of one macromolecule can gradually be tailored by variation of the density of (re)active moities per chain, and of the chain architecture, enabling one to control its interaction (attractive or repulsive) at nanometer distances (e.g. to achieve for instance stealthiness, or stimuli-triggered responses). The range of molecular backbones that are studied to this purpose is becoming large (poly(acrylate) or acrylamide, polynorbornene, poly(styrene), polyamides, modified natural polysaccharides, etc) and simple chemistry affords in most family of macromolecules large variations of structural parameters (e.g. chain length, charge density, hydrophobicity of aliphatic or aromatic side groups). Because this chemical variety has not yet been fully explored, one may consider that developments of synthetic polymers for cell manipulation are in their infancy. Basic guiding rules on structureproperties relationships have however emerged from the data available, and point to the importance of amphiphilicity of polymers.

Researches aiming at optimization of biocides, which are by far the most developed field among researches on polymer-controlled cell, clearly point to critical roles of both 
cationic charge density, and hydrophobicity. It appeared possible to compensate the lower specificity of synthetic macromolecules (compared to peptides) by a subtle balance between fraction of ammonium and alkyl side groups, in order to achieve low hemolytic activities but high antibacterial (MIC $<10 \mu \mathrm{g} / \mathrm{L}$ ) activities. Surprisingly the hydrophobic density of efficient copolymers does not differ significantly from the one of antimicrobial cationic peptides. As for peptides, peculiar enhancement of membrane penetration can be found upon introduction in the chains of guanidinium side group, or phenyl ones, likely because of formation of complexes with lipids. The recognized importance of the amphiphilic nature of cationic artificial biocides does not however suffice to conclude that hydrophobic attachment of polymers in lipid membranes is required. Based on years of investigation of the rich complexity of cell-penetrating peptides and antimicrobial peptides, it is known that multiple steps and several mechanisms are involved in the penetration of macromolecules into cells, including contributions of association in the glycocalix, or with specific lipids. It is however clearly established with model liposomes that amphiphilic polycations (showing biocide activity) bind tightly to lipid bilayers and may translocate when their structure reaches a critical hydrophobicity. On the other hand, upon hydrophobic self-assemblies into micellelike globules, synthetic cationic polymers become markedly less toxic and loss their hemolytic activity. High hydrophobicity, such as the one reached in Amphipol, favors a full collapse/sequestration of the hydrophobic segments into the core of globules, which in turn markedly modify interaction between polymer and cells. In the case of anionic Amphipol, hydrophobic collapse makes the chain capable of solubilizing lipids, which may accelerate membrane breakage in model liposomes. The hydrophobic:hydrophilic balance at the level of either the monomers, or in the whole polymer chain is thus an essential criterion, though monotonous correlation with activity on membranes shall not be expected.

Neutral or anionic chains, and preferably amphiphilic ones, are essentially used as drug-delivery agents or for mild cell coating, suggesting that they are markedly less toxic than cationic ones. Additional functions may be brought by side groups that respond to external stimuli (light, $\mathrm{pH}$ or temperature shift) and enables one to trigger solubility transition. This was successfully exploited to control endosomal escape, or to target cell penetration upon exposure to light or to low $\mathrm{pH}$. Stimuli-controlled polymers include poly(acrylic acid) derivatives belonging to the family of Amphipols and undergoing a transition from watersoluble chains to cell-penetrating ones with decreasing degree of ionization (typically upon decreasing $\mathrm{pH}$ below 5.5-6.5). Membrane breakage and lipid solubilization occurs when they self-associate into micelles. Peptides are also developed as $\mathrm{pH}$-responsive. Future 
developments and sequence adjustments will certainly enable subtle sensitivities to specific biomembranes and environment conditions. In comparison, the chemistry of stimuliresponsive abiotic polymers is not yet suited to design highly specific systems, but its larger toolbox affords new modes of targeting. The adjustment of abrupt transition upon stimulations, specifically using light, can reach high spatial and temporal resolution. It makes no doubt that ongoing progress in the design of bioactive, stimuli-responsive chains for cell manipulation will be actively pursued with the aim to develop abiotic tools for cell therapies, cultures of stem cells (immuno-protection, controlled differentiation), and for studies requiring high spatial control on cell perturbations.

Acknowledgments: EM and CT were supported by "programme Investissement d'Avenir ANR-11-LABX-0011-01". 


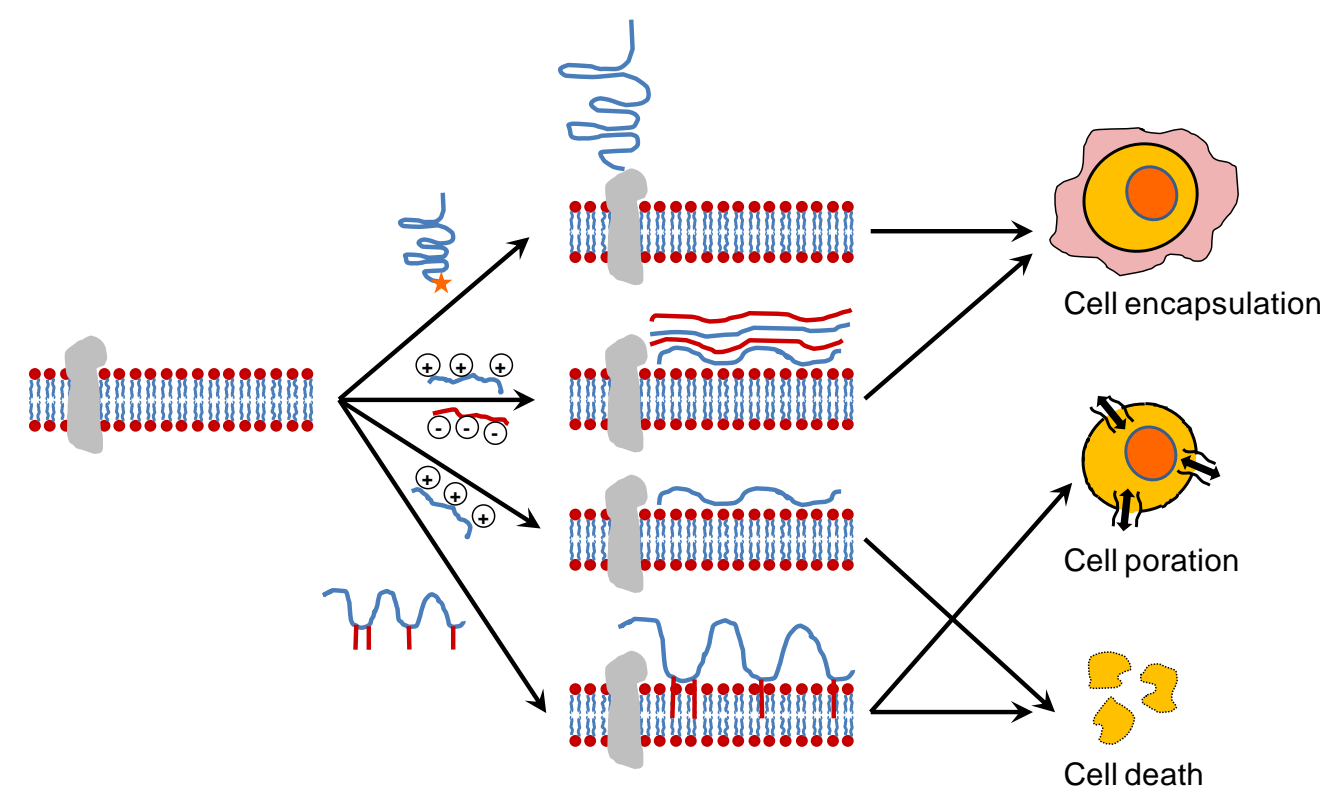

B

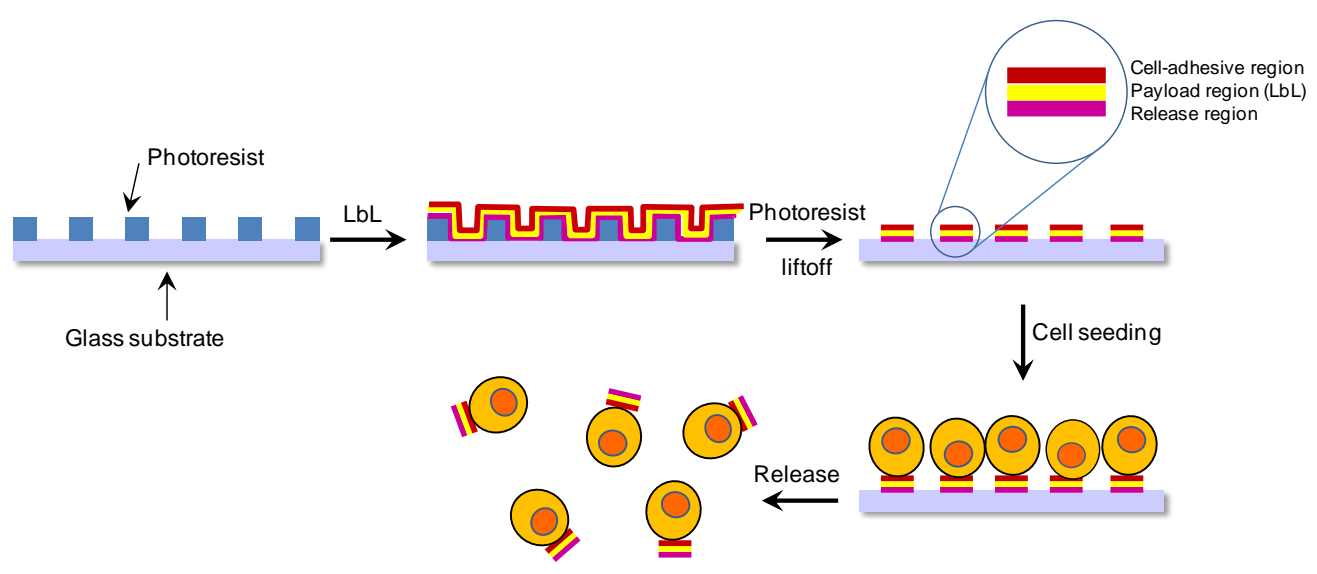

Scheme 1. Drawing of different modes of cell-surface modification and the corresponding applications. (A) from top to bottom, covalent attachment, coulombic binding (monolayer or LbL multilayers), and hydrophobic anchoring of polymers to obtain protective encapsulation (e.g. PEGylation), poration or apoptosis upon binding of either polycations or highly hydrophobic polyamphiphiles; (B) preparation of polyelectrolyte multilayers under the form of micrometer-large patches, "backpacks", attached to macrophage cell carriers: a polymer multilayer film is deposited on glass patterned with photoresist, dissolution of the photoresist leaves intact the fragments of the film that have been deposited on glass. After cell seeding, the adhesion between glass and LbL patches is released by a temperature shift leaving in solution cells attached to one LbL patch. (redrawn from (Swiston AJ et al. 2008; Swiston AJ et al. 2010)) 
A

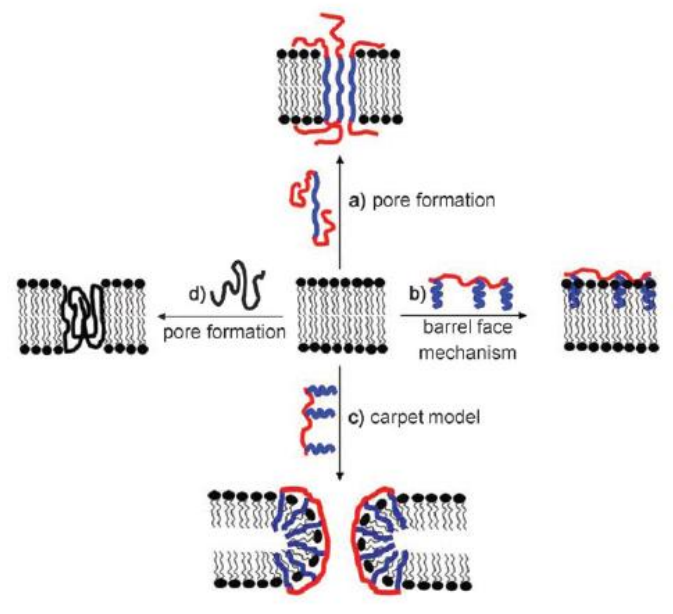

B

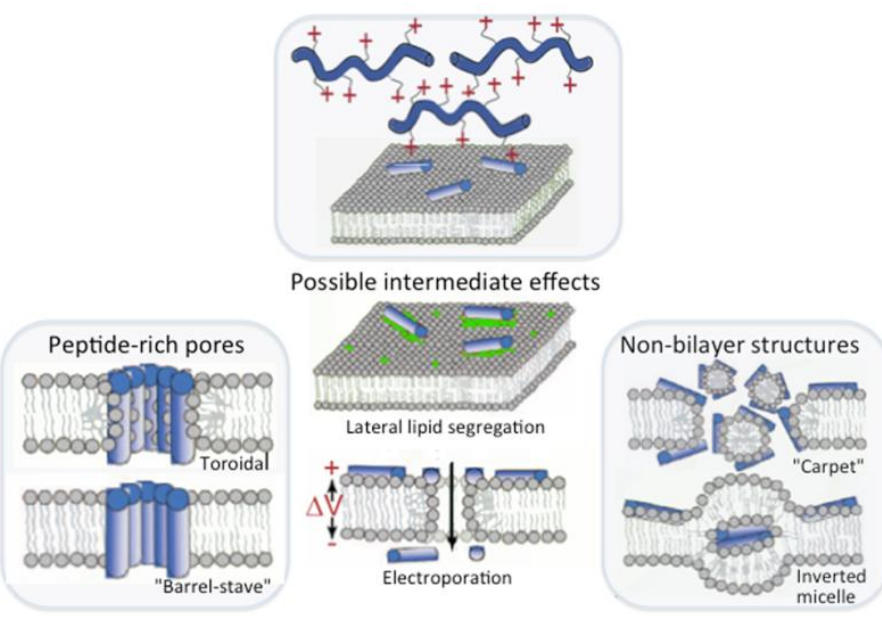

Scheme 2: Drawing of polymer assemblies with lipids that are typically proposed in the literature to illustrate the origin of permeabilization and/or membrane ruptures occurring upon polymer adsorption (A) synthetic (abiotic) copolymers, reprinted with permission from (Binder WH 2008) Copyright 2008 WILEY-VCH Verlag GmbH\&Co.KGaA, Weinheim, (B) models of peptide insertion in lipid membranes. 
Table 1a. Characteristic structures of amphiphilic polymers tailored by adjustment of hydrophobicity to either coat, translocate, permeabilize cells, or kill bacteria. The generic names given in column 3 refer to the main chain, parent polymer without hydrophobic or other functional pendant groups.

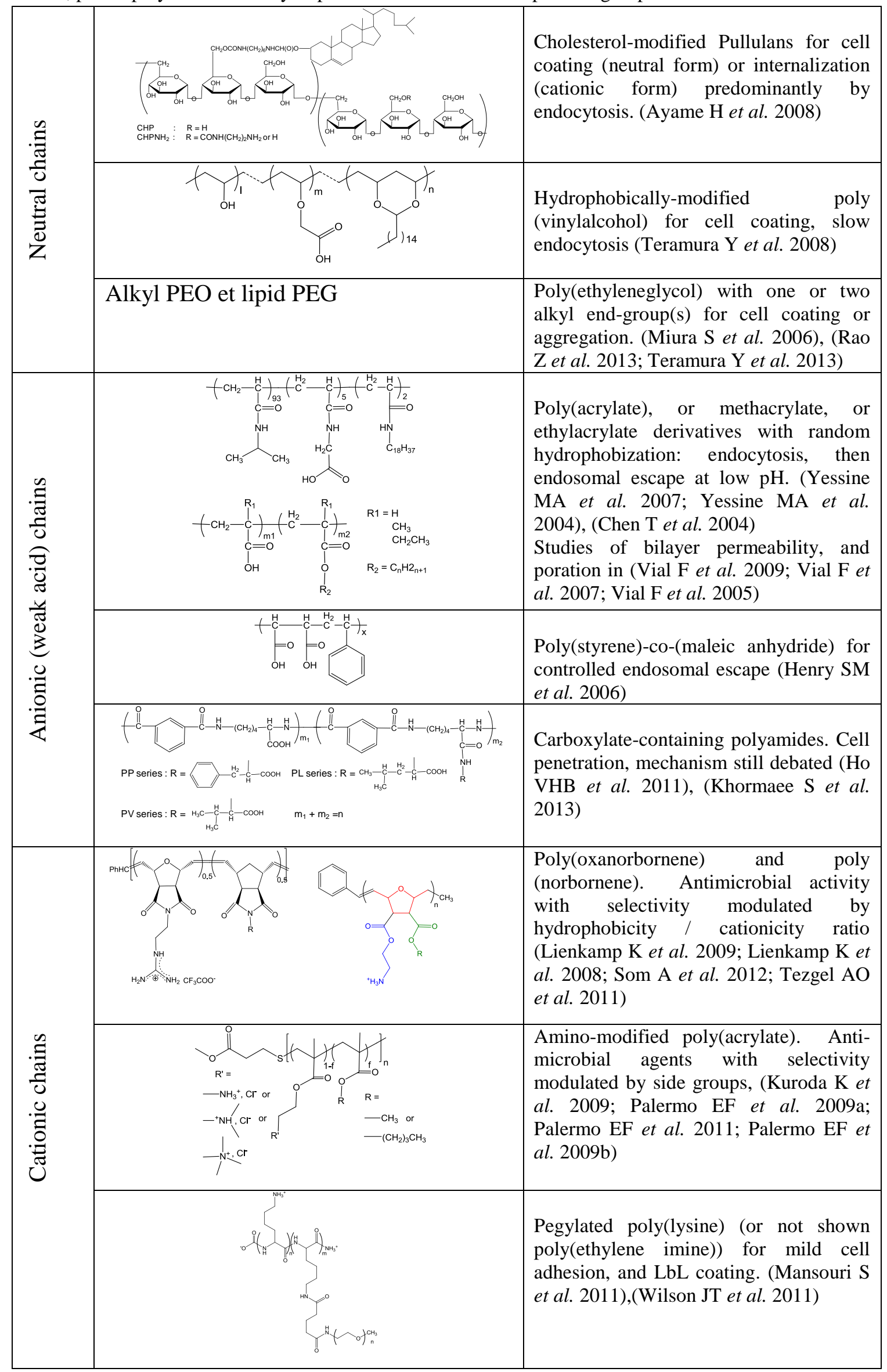


Table 1b. Characteristic structural determinants of stimuli-responsive polymers.

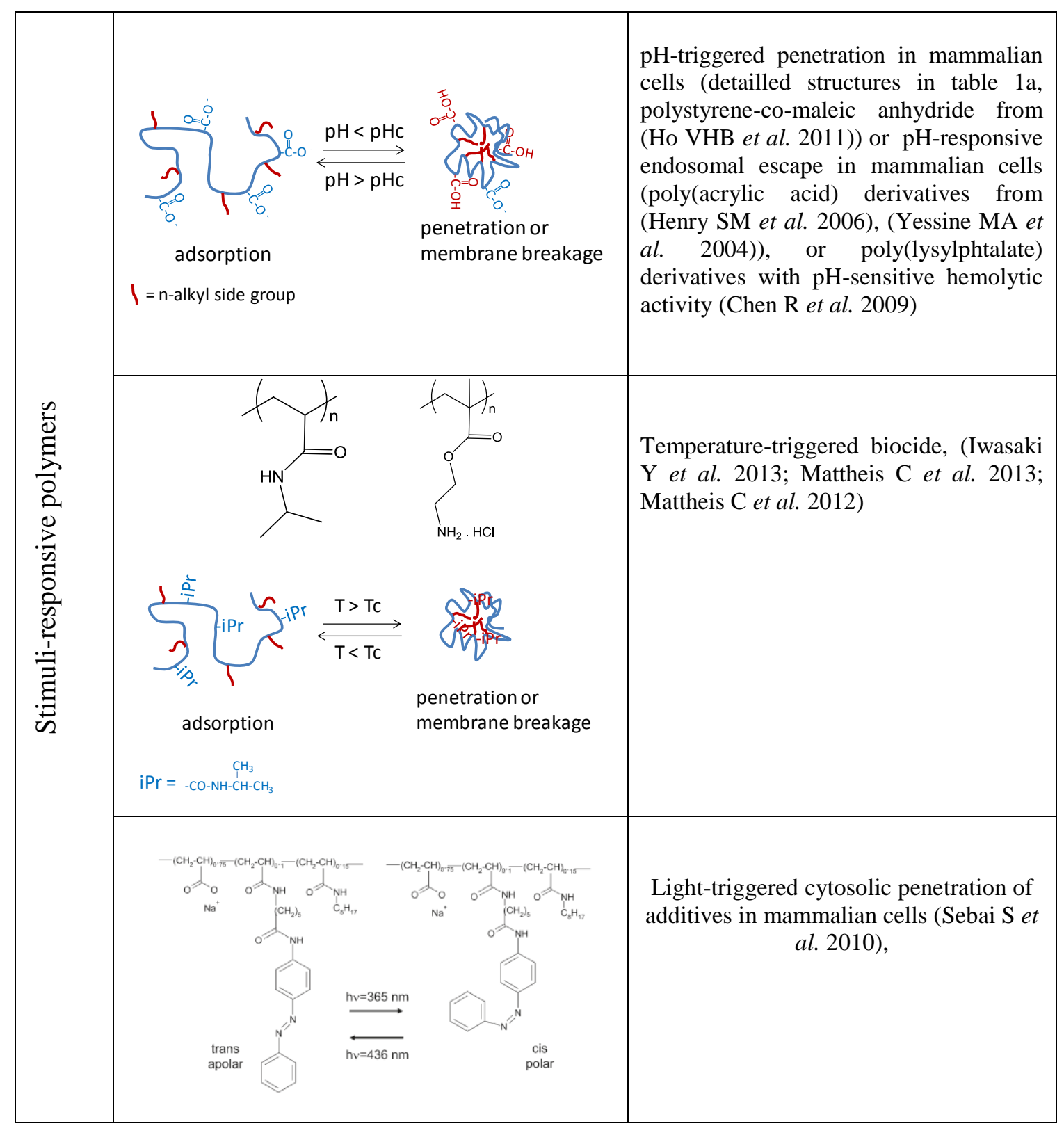



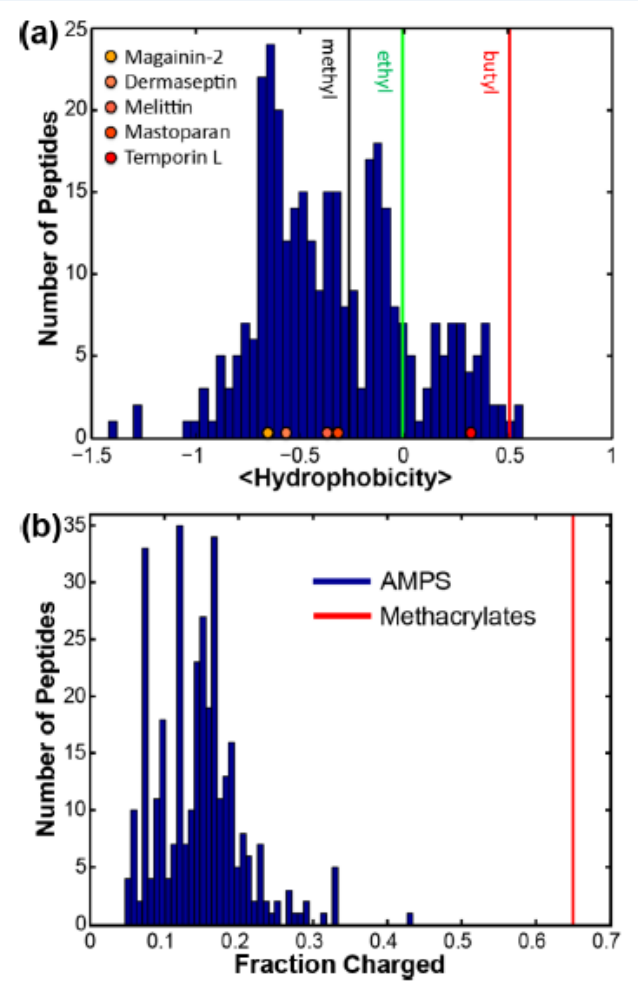

Figure 1: Average hydrophobicity (based on $\log \mathrm{P}$, octanol:water partitioning) and cationic density in biocides polymers belonging to the class of either peptides or poly(acrylate) derivatives. Reprinted with permission from (Hu K et al. 2013) Copyright 2013 American Chemical Society. 
A

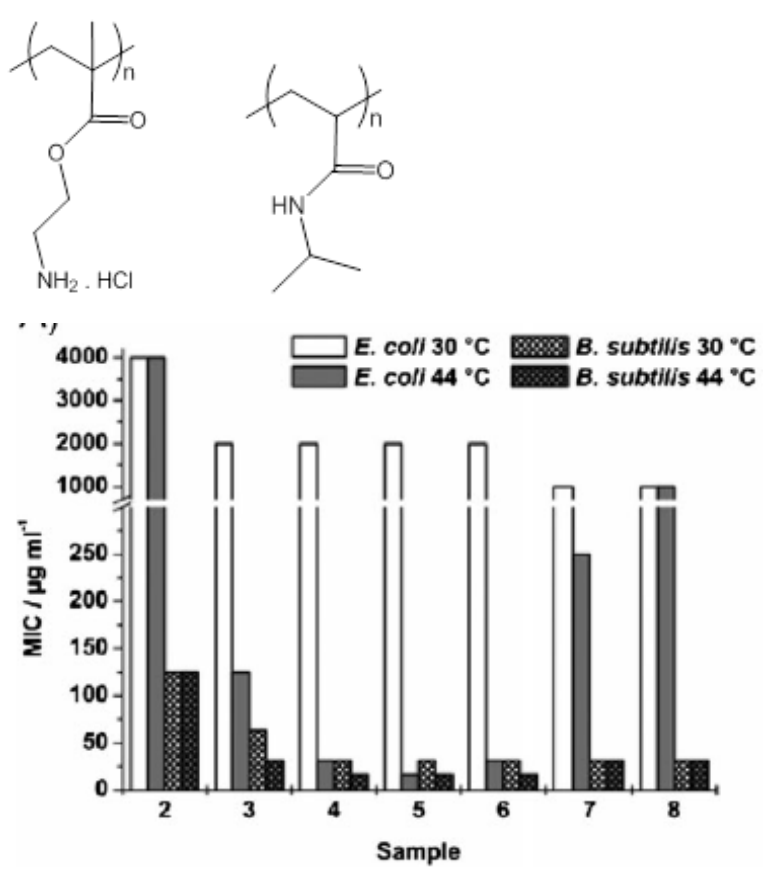

B
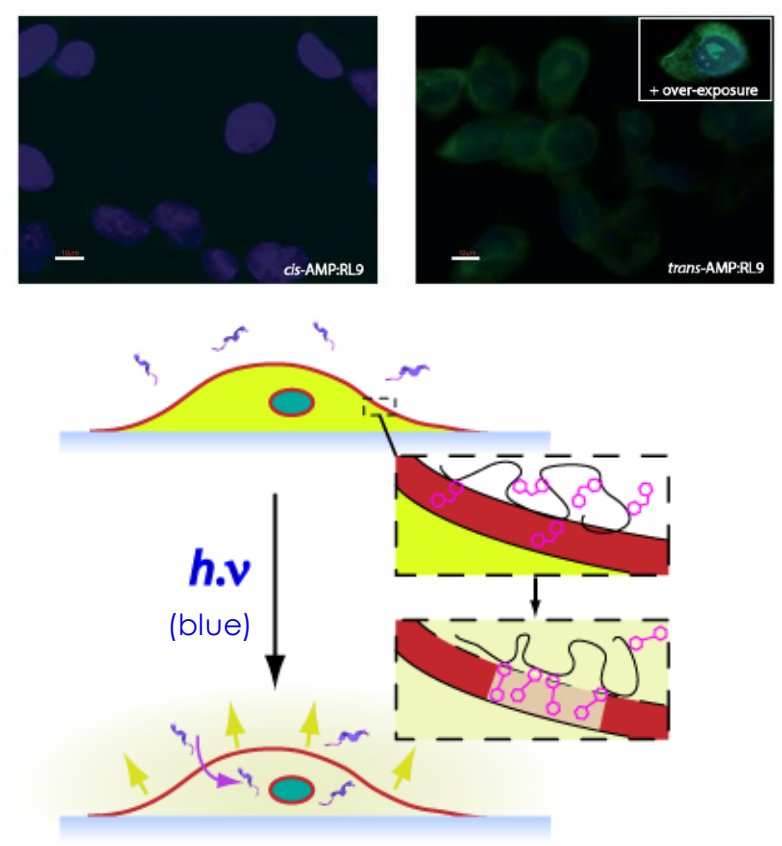

Figure 2. Stimuli-responsive amphiphilicity of polymers controlling cell membranes. (A) temperature-triggered biocide activity, samples from 2 to 7 correspond to increasing fraction (from $10 \mathrm{~mol} \%$ to $54 \mathrm{~mol} \%$ ) of the amino-monomer in the copolymer also shown in Table 1 with transition temperature being in the range $32^{\circ} \mathrm{C}-36^{\circ} \mathrm{C}$; (Mattheis $\mathrm{C}$ et al. 2012) (B) lighttriggered penetration of peptides in cell. Other possible stimuli include temperature or $\mathrm{pH}$. (Sebai S et al. 2010; Sebai SC et al. 2012). Reprinted with permission from (Binder WH 2008), and (Mattheis C et al. 2012) Copyright 2012 WILEY-VCH Verlag GmbH\&Co.KGaA, Weinheim. 


\section{References}

Allen T M, Cullis P R (2013) Liposomal drug delivery systems: From concept to clinical applications. Advanced Drug Delivery Reviews 65(1): 36-48.

Alves I D, Bechara C, Walrant A, Zaltsman Y, Jiao C Y, Sagan S (2011a) Relationships between membrane binding, affinity and cell internalization efficacy of a cell-penetrating peptide: penetratin as a case study. PloS One 6(9): e24096.

Alves I D, Rodriguez N, Cribier S, Sagan S (2011b) Membrane Crossover by Cell-Penetrating Peptides: Kinetics and Mechanisms - From Model to Cell Membrane Perturbation by Permeant Peptides. Fundamental Biomedical Technologies 5: 179-196.

Andaloussi S E, Lehto T, Lundin P, Langel U (2011) Application of PepFect peptides for the delivery of splice-correcting oligonucleotides. Methods Mol. Biol. 683: 361-373.

Andreev O A, Karabadzhak A G, Weerakkody D, Andreev G O, Engelman D M, Reshetnyak Y K (2010) $\mathrm{pH}$ (low) insertion peptide (pHLIP) inserts across a lipid bilayer as a helix and exits by a different path. Proceedings of the National Academy of Sciences of the United States of America 107(9): 4081-4086.

Aroui S, Brahim S, De Waard M, Bréard J, Kenani A (2009) Efficient induction of apoptosis by doxorubicin coupled to cell-penetrating peptides compared to unconjugated doxorubicin in the human breast cancer cell line MDA-MB 231. Cancer Letters 285: 28-38.

Avery C W, Palermo E F, McLaughin A, Kuroda K, Chen Z (2011) Investigations of the Interactions between Synthetic Antimicrobial Polymers and Substrate-Supported Lipid Bilayers Using Sum Frequency Generation Vibrational Spectroscopy. Analytical Chemistry 83(4): 1342-1349.

Ayame H, Morimoto N, Akiyoshi K (2008) Self-assembled cationic nanogels for intracellular protein delivery. Bioconjugate Chemistry 19(4): 882-890.

Bechara C, Pallerla M, Zaltsman Y, Burlina F, Alves I D, Lequin O, Sagan S (2013) Tryptophan within basic peptide sequences triggers glycosaminoglycan-dependent endocytosis. Faseb Journal $27(2)$ : 738-749.

Bechinger B, Aisenbrey C (2012a) The Polymorphic Nature of Membrane-Active Peptides from Biophysical and Structural Investigations. Current Protein \& Peptide Science 13(7): 602-610.

Bechinger B, Aisenbrey C (2012b) The Polymorphic Nature of Membrane-Active Peptides from Biophysical and Structural Investigations. Curr. Prot. Peptide Sci. 13(7): 602-610.

Bechinger B, Zasloff M, Opella S J (1993) Structure and orientation of the antibiotic peptide magainin in membranes by solid-state nuclear magnetic resonance spectroscopy. Protein Sci. 2: 2077-2084.

Berlose J P, Convert O, Derossi D, Brunissen A, Chassaing G (1996) Conformational and associative behaviours of the third helic of antennapedia homeodomain in membrane-mimetic environments. Eur. J. Biochem. 242: 372-386.

Binder W H (2008) Polymer-induced transient pores in lipid membranes. Angewandte ChemieInternational Edition 47(17): 3092-3095.

Binder W H, Barragan V, Menger F M (2003) Domains and rafts in lipid membranes. Angewandte Chemie-International Edition 42(47): 5802-5827.

Bode S A, Thévenin M, Bechara C, Sagan S, Bregant S, Lavielle S, Chassaing G, Burlina F (2012) Selfassembling mini cell-penetrating peptides enter by both direct translocation and glycosaminoglycandependent endocytosis. Chem. Comm. 48: 7179-7181.

Brattwall C E, Lincoln P, Nordén B (2003) Orientation and conformation of cell-penetrating peptide penetratin in phospholipid vesicle membranes determined by polarized-light spectroscopy. J.A.C.S 125: $14214-14215$. 
Chakrabarty S, King A, Kurt P, Zhang W, Ohman D E, Wood L F, Lovelace C, Rao R, Wynne K J (2011) Highly Effective, Water-Soluble, Hemocompatible 1,3-Propylene Oxide-Based Antimicrobials: Poly (3,3-quaternary/PEG)-copolyoxetanes. Biomacromolecules 12(3): 757-769.

Chanana M, Gliozzi A, Diaspro A, Chodnevskaja I, Huewel S, Moskalenko V, Ulrichs K, Galla H J, Krol S (2005) Interaction of polyelectrolytes and their composites with living cells. Nano Letters 5(12): 26052612.

Chandaroy P, Sen A, Alexandridis P, Hui S W (2002) Utilizing temperature-sensitive association of Pluronic F-127 with lipid bilayers to control liposome-cell adhesion. Biochimica Et Biophysica ActaBiomembranes 1559(1): 32-42.

Chen R, Khormaee S, Eccleston M E, Slater N K H (2009) The role of hydrophobic amino acid grafts in the enhancement of membrane-disruptive activity of $\mathrm{pH}$-responsive pseudo-peptides. Biomaterials 30(10): 1954-1961.

Chen T, McIntosh D, He Y, Kim J, Tirrell D A, Scherrer P, Fenske D B, Sandhu A P, Cullis P R (2004) Alkylated derivatives of poly(ethylacrylic acid) can be inserted into preformed liposomes and trigger $\mathrm{pH}$-dependent intracellular delivery of liposomal contents. molecular membrane biology 21: 385393.

Christiaens B, Symoens S, Verheyden S, Engelborghs Y, Joliot A, Prochiantz A, Vandekerckhove J, Rosseneu M, Vanloo B (2002) Tryptophan fluorescence study of the interaction of penetratin peptides with model membranes. Eur. J. Biochem.(269): 2918-2926.

Console S, Marty C, Garcia-Echeverria C, Schwendener R, Ballmer-Hofer K (2003) Antennapedia and HIV transactivator of transcription (TAT) "protein transduction domains" promote endocytosis of high molecular weight cargo upon binding to cell surface glycosaminoglycans. Journal of Biological Chemistry 278(37): 35109-35114.

Cooley C B, Trantow B M, Nederberg F, Kiesewetter M K, Hedrick J L, Waymouth R M, Wender P A (2009) Oligocarbonate Molecular Transporters: Oligomerization-Based Syntheses and CellPenetrating Studies. Journal of the American Chemical Society 131(45): 16401-+.

Couffin-Hoarau A C, Leroux J C (2004) Report on the use of poly(organophosphazenes) for the design of stimuli-responsive vesicles. Biomacromolecules 5(6): 2082-2087.

Crombez L, Morris M C, Dufort S, Aldrian-Herrada G, Nguyen Q, Mc Master G, Coll J L, Heitz F, Divita G (2009) Targeting cyclin B1 through peptide-based delivery of siRNA prevents tumour growth. . Nucleic Acids Res. 37: 4559-4569.

De Koker S, Hoogenboom R, De Geest B G (2012) Polymeric multilayer capsules for drug delivery. Chemical Society Reviews 41(7): 2867-2884.

DeGrado W F, Musso G F, Lieber M, Kaiser E T, Kézdy F J (1982) Kinetics and mechanism of hemolysis induced by melittin and by a synthetic melittin analogue. Biophys. J. 37: 329-338.

Delaroche D, Cantrelle F X, Subra F, Van Heijenoort C, Guittet E, Jiao C Y, Blanchoin L, Chassaing G, Lavielle S, Auclair C, Sagan S (2010) Cell-penetrating Peptides with Intracellular Actin-remodeling Activity in Malignant Fibroblasts. Journal of Biological Chemistry 285(10): 7712-7721.

Demina T, Grozdova I, Krylova O, Zhirnov A, Istratov V, Frey H, Kautz H, Melik-Nubarov N (2005) Relationship between the structure of amphiphilic copolymers and their ability to disturb lipid bilayers. Biochemistry 44(10): 4042-4054.

Derossi D, Joliot A H, Chassaing G, Prochiantz A (1994) THE 3RD HELIX OF THE ANTENNAPEDIA HOMEODOMAIN TRANSLOCATES THROUGH BIOLOGICAL-MEMBRANES. Journal of Biological Chemistry 269(14): 10444-10450. 
Deshayes S, Konate K, Rydstrom A, Crombez L, Godefroy C, Milhiet P E, Thomas A, Brasseur R, Aldrian G, Heitz F, Munoz-Morris M A, Devoisselle J M, Divita G (2012) Self-Assembling Peptide-Based Nanoparticles for siRNA Delivery in Primary Cell Lines. Small 8(14): 2184-2188.

Devaraj N K, Thurber G M, Keliher E J, Marinelli B, Weissleder R (2012) Reactive polymer enables efficient in vivo bioorthogonal chemistry. Proceedings of the National Academy of Sciences of the United States of America 109(13): 4762-4767.

Diaspro A, Silvano D, Krol S, Cavalleri O, Gliozzi A (2002) Single living cell encapsulation in nanoorganized polyelectrolyte shells. Langmuir 18(13): 5047-5050.

Dizman B, Elasri M O, Mathias L J (2004) Synthesis and antimicrobial activities of new water-soluble bis-quaternary ammonium methacrylate polymers. Journal of Applied Polymer Science 94(2): 635642.

Doshi N, Swiston A J, Gilbert J B, Alcaraz M L, Cohen R E, Rubner M F, Mitragotri S (2011) Cell-Based Drug Delivery Devices Using Phagocytosis-Resistant Backpacks. Advanced Materials 23(12): H105H109.

Eccleston M E, Kuiper M, Gilchrist F M, Slater N K H (2000) pH-responsive pseudo-peptides for cell membrane disruption. Journal of Controlled Release 69(2): 297-307.

Epand R F, Mor A, Epand R M (2011) Lipid complexes with cationic peptides and OAKs; their role in antimicrobial action and in the delivery of antimicrobial agents. Cellular and Molecular Life Sciences 68(13): 2177-2188.

Fakhrullin R F, Zamaleeva A I, Minullina R T, Konnova S A, Paunov V N (2012) Cyborg cells: functionalisation of living cells with polymers and nanomaterials. Chemical Society Reviews 41(11): 4189-4206.

Fakhrullin R F, Zamaleeva A I, Morozov M V, Tazetdinova D I, Alimova F K, Hilmutdinov A K, Zhdanov R I, Kahraman M, Culha M (2009) Living Fungi Cells Encapsulated in Polyelectrolyte Shells Doped with Metal Nanoparticles. Langmuir 25(8): 4628-4634.

Ferri J K, Miller R, Makievski A V (2005) Equilibrium and dynamics of PEO/PPO/PEO penetration into DPPC monolayers. Colloids and Surfaces a-Physicochemical and Engineering Aspects 261(1-3): 39-48.

Fillon Y A, Anderson J P, Chmielewski J (2005) Cell penetrating agents based on a polyproline helix scaffold. Journal of the American Chemical Society 127(33): 11798-11803.

Firestone M A, Seifert S (2005) Interaction of nonionic PEO-PPO diblock copolymers with lipid bilayers. Biomacromolecules 6(5): 2678-2687.

Fischer D, Li Y X, Ahlemeyer B, Krieglstein J, Kissel T (2003) In vitro cytotoxicity testing of polycations: influence of polymer structure on cell viability and hemolysis. Biomaterials 24(7): 1121-1131.

Francis M F, Dhara G, Winnik F M, Leroux J C (2001) In vitro evaluation of pH-sensitive polymer/niosome complexes. Biomacromolecules 2(3): 741-749.

Franz B, Balkundi S S, Dahl C, Lvov Y M, Prange A (2010) Layer-by-Layer Nano-Encapsulation of Microbes: Controlled Cell Surface Modification and Investigation of Substrate Uptake in Bacteria. Macromolecular Bioscience 10(2): 164-172.

Futaki S, Nakase I, Suzuki T, Zhang Y J, Sugiura Y (2002) Translocation of branched-chain arginine peptides through cell membranes: Flexibility in the spatial disposition of positive charges in membrane-permeable peptides. Biochemistry 41(25): 7925-7930.

Futaki S, Suzuki T, Ohashi W, Yagami T, Tanaka S, Ueda K, Sugiura Y (2001) Arginine-rich peptides - An abundant source of membrane-permeable peptides having potential as carriers for intracellular protein delivery. Journal of Biological Chemistry 276(8): 5836-5840. 
Gabriel G J, Pool J G, Som A, Dabkowski J M, Coughlin E B, Muthukurnar M, Tew G N (2008) Interactions between Antimicrobial Polynorbornenes and Phospholipid Vesicles Monitored by Light Scattering and Microcalorimetry. Langmuir 24(21): 12489-12495.

Garg P, Debnath T, Chelluri L K, Hebalkar N (2012) Feasibility of Polymer Based Cell Encapsulation Using Electrostatic Layer by Layer Assembly. Journal Of Biomaterials And Tissue Engineering 2(3): 215-219.

Georghiou S, Thompson M, Mukhopadhyay A K (1982) MELITTIN-PHOSPHOLIPID INTERACTION STUDIED BY EMPLOYING THE SINGLE TRYPTOPHAN RESIDUE AS AN INTRINSIC FLUORESCENT-PROBE. Biochimica Et Biophysica Acta 688(2): 441-452.

Germain M, Balaguer P, Nicolas J C, Lopez F, Esteve J P, Sukhorukov G B, Winterhalter M, Richard-Foy $\mathrm{H}$, Fournier D (2006) Protection of mammalian cell used in biosensors by coating with a polyelectrolyte shell. Biosensors \& Bioelectronics 21(8): 1566-1573.

Giangaspero A, Sandri L, Tossi A (2001) Amphipathic alpha helical antimicrobial peptides - A systematic study of the effects of structural and physical properties on biological activity. European Journal of Biochemistry 268(21): 5589-5600.

Giusti F, Popot J L, Tribet C (2012) Well-Defined Critical Association Concentration and Rapid Adsorption at the Air/Water Interface of a Short Amphiphilic Polymer, Amphipol A8-35: A Study by Forster Resonance Energy Transfer and Dynamic Surface Tension Measurements. Langmuir 28(28): 10372-10380.

Goda T, Goto Y, Ishihara K (2010) Cell-penetrating macromolecules: Direct penetration of amphipathic phospholipid polymers across plasma membrane of living cells. Biomaterials 31(8): 2380-2387.

Guo Z J, Kallus S, Akiyoshi K, Sunamoto J (1995) ARTIFICIAL CELL-WALL FOR PLANT PROTOPLAST COATING OF PLASMA-MEMBRANE WITH HYDROPHOBIZED POLYSACCHARIDES. Chemistry Letters(6): 415-416.

Harris F, Dennison S R, Singh J, Phoenix D A (2013) On the selectivity and efficacy of defense peptides with respect to cancer cells. Medicinal Research Reviews 33(1): 190-234.

He Y C, Heine E, Keusgen N, Keul H, Moller M (2012) Synthesis and Characterization of Amphiphilic Monodisperse Compounds and Poly(ethylene imine)s: Influence of Their Microstructures on the Antimicrobial Properties. Biomacromolecules 13(3): 612-623.

Hennig A, Gabriel G J, Tew G N, Matile S (2008) Stimuli-responsive polyguanidino-oxanorbornene membrane transporters as multicomponent sensors in complex matrices. Journal of the American Chemical Society 130(31): 10338-10344.

Henry S M, El-Sayed M E H, Pirie C M, Hoffman A S, Stayton P S (2006) pH-responsive poly(styrenealt-maleic anhydride) alkylamide copolymers for intracellular drug delivery. Biomacromolecules 7(8): 2407-2414.

Ho V H B, Slater N K H, Chen R J (2011) pH-responsive endosomolytic pseudo-peptides for drug delivery to multicellular spheroids tumour models. Biomaterials 32(11): 2953-2958.

Hoffman A S, Stayton P S, Press O, Murthy N, Lackey C A, Cheung C, Black F, Campbell J, Fausto N, Kyriakides T R, Bornstein P (2002) Design of "smart" polymers that can direct intracellular drug delivery. Polymers for Advanced Technologies 13(10-12): 992-999.

Holowka E P, Sun V Z, Kamei D T, Deming T J (2007) Polyarginine segments in block copolypeptides drive both vesicular assembly and intracellular delivery. Nature Materials 6(1): 52-57.

Hong S P, Leroueil P R, Janus E K, Peters J L, Kober M M, Islam M T, Orr B G, Baker J R, Holl M M B (2006) Interaction of polycationic polymers with supported lipid bilayers and cells: Nanoscale hole formation and enhanced membrane permeability. Bioconjugate Chemistry 17(3): 728-734. 
Hoskin D W, Ramamoorthy A (2008) Studies on anticancer activities of antimicrobial peptides. Biochimica Et Biophysica Acta-Biomembranes 1778(2): 357-375.

Hu K, Schmidt N W, Zhu R, Jiang Y J, Lai G H, Wei G, Palermo E F, Kuroda K, Wong G C L, Yang L H (2013) A Critical Evaluation of Random Copolymer Mimesis of Homogeneous Antimicrobial Peptides. Macromolecules 46(5): 1908-1915.

Hu X L, Jing X B (2009) Biodegradable amphiphilic polymer-drug conjugate micelles. Expert Opinion on Drug Delivery 6(10): 1079-1090.

Huin C, Gall T L, Barteau B, Pitard B, Montier T, Lehn P, Cheradame H, Guégan P (2011) Evidence of DNA transfer across a model membrane by a neutral amphiphilic block copolymer. THE JOURNAL OF GENE MEDICINE 13: 538-548.

Ishitsuka Y, Arnt L, Majewski J, Frey S, Ratajczek M, Kjaer K, Tew G N, Lee K Y C (2006) Amphiphilic poly(phenyleneethynylene)s can mimic antimicrobial peptide membrane disordering effect by membrane insertion. Journal of the American Chemical Society 128(40): 13123-13129.

Ito M, Taguchi T (2009) Enhanced insulin secretion of physically crosslinked pancreatic beta-cells by using a poly(ethylene glycol) derivative with oleyl groups. Acta Biomaterialia 5(8): 2945-2952.

Iwasaki Y, Sakiyama M, Fujii S, Yusa S (2013) Surface modification of mammalian cells with stimuliresponsive polymers. Chemical Communications 49(71): 7824-7826.

Jiao C Y, Delaroche D, Burlina F, Alves I D, Chassaing G, Sagan S (2009) Translocation and Endocytosis for Cell-penetrating Peptide Internalization. Journal of Biological Chemistry 284(49): 33957-33965.

Khandelia H, Ipsen J H, Mouritsen O G (2008) The impact of peptides on lipid membranes. Biochimica Et Biophysica Acta-Biomembranes 1778(7-8): 1528-1536.

Khormaee S, Choi Y, Shen M J, Xu B Y, Wu H T, Griffiths G L, Chen R J, Slater N K H, Park J K (2013) Endosomolytic Anionic Polymer for the Cytoplasmic Delivery of siRNAs in Localized In Vivo Applications. Advanced Functional Materials 23(5): 565-574.

Kim J C, Kim J D (2002) Release property of temperature-sensitive liposome containing poly(Nisopropylacrylamide). Colloids and Surfaces B-Biointerfaces 24(1): 45-52.

Koren E, Torchilin V P (2012) Cell-penetrating peptides: breaking through to the other side. Trends in Molecular Medicine 18(7): 385-393.

Krol S, del Guerra S, Grupillo M, Diaspro A, Gliozzi A, Marchetti P (2006) Multilayer nanoencapsulation. New approach for immune protection of human pancreatic islets. Nano Letters 6(9): 1933-1939.

Kuroda K, Caputo G A, DeGrado W F (2009) The Role of Hydrophobicity in the Antimicrobial and Hemolytic Activities of Polymethacrylate Derivatives. Chemistry-a European Journal 15(5): 11231133.

Kusonwiriyawong C, van de Wetering P, Hubbell J A, Merkle H P, Walter E (2003) Evaluation of pHdependent membrane-disruptive properties of poly(acrylic acid) derived polymers. European Journal of Pharmaceutics and Biopharmaceutics 56(2): 237-246.

Lackey C A, Murthy N, Press O W, Tirrell D A, Hoffman A S, Stayton P S (1999) Hemolytic activity of pH-responsive polymer-streptavidin bioconjugates. Bioconjugate Chemistry 10(3): 401-405.

Ladaviere C, Tribet C, Cribier S (2002) Lateral organization of lipid membranes induced by amphiphilic polymer inclusions. Langmuir 18(20): 7320-7327.

Ladokhin A S, White S H (2001) 'Detergent-like' permeabilization of anionic lipid vesicles by melittin. Biochimica Et Biophysica Acta-Biomembranes 1514(2): 253-260.

Last N B, Schlamadinger D E, Miranker A D (2013) A common landscape for membrane-active peptides. Protein Science 22(7): 870-882. 
le Maire M, Champeil P, Moller J V (2000) Interaction of membrane proteins and lipids with solubilizing detergents. Biochimica Et Biophysica Acta-Biomembranes 1508(1-2): 86-111.

Lee H S, Park C B, Kim J M, Jang S A, Park I Y, Kim M S, Cho J H, Kim S C (2008) Mechanism of anticancer activity of buforin IIb, a histone H2A-derived peptide. Cancer Letters 271(1): 47-55.

Liechty W B, Kryscio D R, Slaughter B V, Peppas N A (2010). Polymers for Drug Delivery Systems. Annual Review of Chemical and Biomolecular Engineering, Vol 1. J. M. Prausnitz, M. F. Doherty and M. A. Segalman. 1: 149-173.

Lienkamp K, Kumar K N, Som A, Nusslein K, Tew G N (2009) "Doubly Selective" Antimicrobial Polymers: How Do They Differentiate between Bacteria? Chemistry-a European Journal 15(43): 11710-11714.

Lienkamp K, Madkour A, Musante A, Nelson C, Nusslein K, Tew G N (2008) Antimicrobial Polymers Prepared by ROMP with Unprecedented Selectivity: A Molecular Construction Kit Approach. J.A.C.S. 130: 9836-9843.

Madani F, Abdo R, Lindberg S, Hirose H, Futaki S, Langel U, Graslund A (2013) Modeling the endosomal escape of cell-penetrating peptides using a transmembrane $\mathrm{pH}$ gradient. Biochimica Et Biophysica Acta-Biomembranes 1828(4): 1198-1204.

Magzoub M, Eriksson L E G, Graslund A (2002) Conformational states of the cell-penetrating peptide penetratin when interacting with phospholipid vesicles: effects of surface charge and peptide concentration. Biochimica Et Biophysica Acta-Biomembranes 1563(1-2): 53-63.

Mansouri S, Merhi Y, Winnik F M, Tabrizian M (2011) Investigation of Layer-by-Layer Assembly of Polyelectrolytes on Fully Functional Human Red Blood Cells in Suspension for Attenuated Immune Response. Biomacromolecules 12(3): 585-592.

Matile S, Jentzsch A V, Montenegro J, Fin A (2011) Recent synthetic transport systems. Chemical Society Reviews 40(5): 2453-2474.

Matsuda M, Ueno M, Endo Y, Inoue M, Sasaki M, Taguchi T (2012) Enhanced tissue penetrationinduced high bonding strength of a novel tissue adhesive composed of cholesteryl group-modified gelatin and disuccinimidyl tartarate. Colloids and Surfaces B-Biointerfaces 91: 48-56.

Matsuzaki K, Murase O, Miyajima K (1995) KINETICS OF PORE FORMATION BY AN ANTIMICROBIAL PEPTIDE, MAGAININ-2, IN PHOSPHOLIPID-BILAYERS. Biochemistry 34(39): 12553-12559.

Mattheis C, Wang H, Meister C, Agarwal S (2013) Effect of Guanidinylation on the Properties of Poly(2-aminoethylmethacrylate)-Based Antibacterial Materials. Macromolecular Bioscience 13(2): 242-255.

Mattheis C, Zhang Y, Agarwal S (2012) Thermo-Switchable Antibacterial Activity. Macromolecular Bioscience 12(10): 1401-1412.

Meng X T, Xing R G, Liu S, Yu H H, Li K C, Qin Y K, Li P C (2012) Molecular weight and pH effects of aminoethyl modified chitosan on antibacterial activity in vitro. International Journal of Biological Macromolecules 50(4): 918-924.

Milletti F (2012) Cell-penetrating peptides: classes, origin, and current landscape. Drug Discovery Today 17(15-16): 850-860.

Mitchell D J, Kim D T, Steinman L, Fathman C G, Rothbard J B (2000) Polyarginine enters cells more efficiently than other polycationic homopolymers. Journal of Peptide Research 56(5): 318-325.

Miura S, Teramura Y, Iwata H (2006) Encapsulation of islets with ultra-thin polyion complex membrane through poly(ethylene glycol)-phospholipids anchored to cell membrane. Biomaterials 27(34): 5828-5835. 
Mollay C, Kreil G (1973) FLUOROMETRIC MEASUREMENTS ON INTERACTION OF MELITTIN WITH LECITHIN. Biochimica Et Biophysica Acta 316(2): 196-203.

Mollay C, Kreil G, Berger H (1976) ACTION OF PHOSPHOLIPASES ON CYTOPLASMIC MEMBRANE OF ESCHERICHIA-COLI - STIMULATION BY MELITTIN. Biochimica Et Biophysica Acta 426(2): 317-324.

Munoz-Bonilla A, Fernandez-Garcia M (2012) Polymeric materials with antimicrobial activity. Progress in Polymer Science 37(2): 281-339.

Nakase I, Akita H, Kogure K, Graslund A, Langel U, Harashima H, Futaki S (2012a) Efficient Intracellular Delivery of Nucleic Acid Pharmaceuticals Using Cell-Penetrating Peptides. Accounts of Chemical Research 45(7): 1132-1139.

Nakase I, Konishi Y, Ueda M, Saji H, Futaki S (2012b) Accumulation of arginine-rich cell-penetrating peptides in tumors and the potential for anticancer drug delivery in vivo. Journal of Controlled Release 159(2): 181-188.

Nakase I, Okumura S, Katayama S, Hirose H, Pujals S, Yamaguchi H, Arakawa S, Shimizu S, Futaki S (2012c) Transformation of an antimicrobial peptide into a plasma membrane-permeable, mitochondria-targeted peptide via the substitution of lysine with arginine. Chemical Communications 48(90): 11097-11099.

Neu B, Voigt A, Mitlohner R, Leporatti S, Gao C Y, Donath E, Kiesewetter H, Mohwald H, Meiselman H J, Baumler H (2001) Biological cells as templates for hollow microcapsules. Journal of Microencapsulation 18(3): 385-395.

Nguyen L T, Haney E F, Vogel H J (2011) The expanding scope of antimicrobial peptide structures and their modes of action. Trends in Biotechnology 29(9): 464-472.

Nicolas J, Mura S, Brambilla D, Mackiewicz N, Couvreur P (2013) Design, functionalization strategies and biomedical applications of targeted biodegradable/biocompatible polymer-based nanocarriers for drug delivery. Chemical Society Reviews 42(3): 1147-1235.

Nochi T, Yuki Y, Takahashi H, Sawada S, Mejima M, Kohda T, Harada N, Kong I G, Sato A, Kataoka N, Tokuhara D, Kurokawa S, Takahashi Y, Tsukada H, Kozaki S, Akiyoshi K, Kiyono H (2010) Nanogel antigenic protein-delivery system for adjuvant-free intranasal vaccines. Nature Materials 9(7): 572578.

Oda Y, Kanaoka S, Sato T, Aoshima S, Kuroda K (2011) Block versus Random Amphiphilic Copolymers as Antibacterial Agents. Biomacromolecules 12(10): 3581-3591.

Pack D W, Hoffman A S, Pun S, Stayton P S (2005) Design and development of polymers for gene delivery. Nature Reviews Drug Discovery 4(7): 581-593.

Palermo E F, Kuroda K (2009a) Chemical Structure of Cationic Groups in Amphiphilic Polymethacrylates Modulates the Antimicrobial and Hemolytic Activities. Biomacromolecules 10(6): 1416-1428.

Palermo E F, Lee D K, Ramamoorthy A, Kuroda K (2011) Role of Cationic Group Structure in Membrane Binding and Disruption by Amphiphilic Copolymers. Journal of Physical Chemistry B 115(2): 366-375.

Palermo E F, Sovadinova I, Kuroda K (2009b) Structural Determinants of Antimicrobial Activity and Biocompatibility in Membrane-Disrupting Methacrylamide Random Copolymers. Biomacromolecules 10(11): 3098-3107.

Palermo E F, Vemparala S, Kuroda K (2012) Cationic Spacer Arm Design Strategy for Control of Antimicrobial Activity and Conformation of Amphiphilic Methacrylate Random Copolymers. Biomacromolecules 13(5): 1632-1641. 
Papo N, Seger D, Makovitzki A, Kalchenko V, Eshhar Z, Degani H, Shai Y (2006) Inhibition of tumor growth and elimination of multiple metastases in human prostate and breast xenografts by systemic inoculation of a host defense-like lytic peptide. Cancer Research 66(10): 5371-5378.

Papo N, Shai Y (2003) Exploring peptide membrane interaction using surface plasmon resonance: Differentiation between pore formation versus membrane disruption by lytic peptides. Biochemistry 42(2): 458-466.

Pashkovskaya A A, Lukashev E P, Antonov P E, A.Finogenova O, Ermakov Y A, Melik-Nubarov N S, Antonenko Y N (2006) Biochim. Biophys. Acta 1758: 1685-1695.

Paslay L C, Abel B A, Brown T D, Koul V, Choudhary V, McCormick C L, Morgan S E (2012) Antimicrobial Poly(methacrylamide) Derivatives Prepared via Aqueous RAFT Polymerization Exhibit Biocidal Efficiency Dependent upon Cation Structure. Biomacromolecules 13(8): 2472-2482.

Paulmann M, Arnold T, Linke D, Oezdirekcan S, Kopp A, Gutsmann T, Kalbacher H, Wanke I, Schuenemann V J, Habeck M, Buerck J, Ulrich A S, Schittek B (2012) Structure-Activity Analysis of the Dermcidin-derived Peptide DCD-1L, an Anionic Antimicrobial Peptide Present in Human Sweat. Journal of Biological Chemistry 287(11): 8434-8443.

Persson D, Thoren P E G, Lincoln P, Norden B (2004) Vesicle membrane interactions of penetratin analogues. Biochemistry 43(34): 11045-11055.

Poon G M K, Gariepy J (2007) Cell-surface proteoglycans as molecular portals for cationic peptide and polymer entry into cells. Biochemical Society Transactions 35: 788-793.

Popot J L, Althoff T, Bagnard D, Baneres J L, Bazzacco P, Billon-Denis E, Catoire L J, Champeil P, Charvolin D, Cocco M J, Cremel G, Dahmane T, de la Maza L M, Ebel C, Gabel F, Giusti F, Gohon Y, Goormaghtigh E, Guittet E, Kleinschmidt J H, Kuhlbrandt W, Le Bon C, Martinez K L, Picard M, Pucci B, Sachs J N, Tribet C, van Heijenoort C, Wien F, Zito F, Zoonens M (2011) Amphipols From A to Z. Annual Review of Biophysics, Vol 40 40: 379-408.

Pourmousa M, Karttunen M (2013) Early stages of interactions of cell-penetrating peptide penetratin with a DPPC bilayer. Chemistry and Physics of Lipids 169: 85-94.

Rao Z, Sasaki M, Taguchi T (2013) Development of amphiphilic, enzymatically-degradable PEGpeptide conjugate as cell crosslinker for spheroid formation. Colloids and Surfaces B-Biointerfaces 101: 223-227.

Relogio P, Bathfield M, Haftek-Terreau Z, Beija M, Favier A, Giraud-Panis M J, D'Agosto F, Mandrand B, Farinha J P S, Charreyre M T, Martinho J M G (2013) Biotin-end-functionalized highly fluorescent water-soluble polymers. Polymer Chemistry 4(10): 2968-2981.

Riedl S, Zweytick D, Lohner K (2011) Membrane-active host defense peptides - Challenges and perspectives for the development of novel anticancer drugs. Chemistry and Physics of Lipids 164(8): 766-781.

Ringsdorf H, Sackmann E, Simon J, Winnik F M (1993) Interactions of Liposomes and HydrophobicallyModified Poly-(N-Isopropylacrylamides) - an Attempt to Model the Cytoskeleton. Biochimica Et Biophysica Acta 1153(2): 335-344.

Rothbard J B, Garlington S, Lin Q, Kirschberg T, Kreider E, McGrane P L, Wender P A, Khavari P A (2000) Conjugation of arginine oligomers to cyclosporin A facilitates topical delivery and inhibition of inflammation. Nature Medicine 6(11): 1253-1257.

Rothbard J B, Jessop T C, Lewis R S, Murray B A, Wender P A (2004) Role of membrane potential and hydrogen bonding in the mechanism of translocation of guanidinium-rich peptides into cells. Journal of the American Chemical Society 126(31): 9506-9507. 
Rothbard J B, Jessop T C, Wender P A (2005) Adaptive translocation: the role of hydrogen bonding and membrane potential in the uptake of guanidinium-rich transporters into cells. Advanced Drug Delivery Reviews 57(4): 495-504.

Roux E, Lafleur M, Lataste E, Moreau P, Leroux J C (2003) On the characterization of pH-sensitive liposome/polymer complexes. Biomacromolecules 4(2): 240-248.

Schulz M, Olubummo A, Binder W H (2012) Beyond the lipid-bilayer: interaction of polymers and nanoparticles with membranes. Soft Matter 8(18): 4849-4864.

Scott M D, Murad K L, Koumpouras F, Talbot M, Eaton J W (1997) Chemical camouflage of antigenic determinants: Stealth erythrocytes. Proceedings of the National Academy of Sciences of the United States of America 94(14): 7566-7571.

Sebai S, Cribier S, Karimi A, Massotte D, Tribet C (2010) Permeabilization of lipid membranes and cells by a light-responsive copolymer. Langmuir 26(17): 14135-14141.

Sebai S C, Milioni D, Walrant A, Alves I D, Sagan S, Huin C, Auvray L, Massotte D, Cribier S, Tribet C (2012) Photocontrol of the Translocation of Molecules, Peptides, and Quantum Dots through Cell and Lipid Membranes Doped with Azobenzene Copolymers. Angewandte Chemie-International Edition 51(9): 2132-2136.

Shokeen M, Pressly E D, Hagooly A, Zheleznyak A, Ramos N, Fiamengo A L, Welch M J, Hawker C J, Anderson C J (2011) Evaluation of Multivalent, Functional Polymeric Nanoparticles for Imaging Applications. Acs Nano 5(2): 738-747.

Siedenbiedel F, Tiller J C (2012) Antimicrobial Polymers in Solution and on Surfaces: Overview and Functional Principles. Polymers 4(1): 46-71.

Som A, Reuter A, Tew G N (2012) Protein Transduction Domain Mimics: The Role of Aromatic Functionality. Angewandte Chemie-International Edition 51(4): 980-983.

Sovadinova I, Palermo E F, Huang R, Thoma L M, Kuroda K (2011a) Mechanism of Polymer-Induced Hemolysis: Nanosized Pore Formation and Osmotic Lysis. Biomacromolecules 12(1): 260-268.

Sovadinova I, Palermo E F, Urban M, Mpiga P, Caputo G A, Kuroda K (2011b) Activity and Mechanism of Antimicrobial Peptide-Mimetic Amphiphilic Polymethacrylate Derivatives. Polymers 3(3): 15121532.

Stratton T R, Applegate B M, Youngblood J P (2011) Effect of Steric Hindrance on the Properties of Antibacterial and Biocompatible Copolymers. Biomacromolecules 12(1): 50-56.

Suzuki T, Futaki S, Niwa M, Tanaka S, Ueda K, Sugiura Y (2002) Possible existence of common internalization mechanisms among arginine-rich peptides. Journal of Biological Chemistry 277(4): 2437-2443.

Swiston A J, Cheng C, Um S H, Irvine D J, Cohen R E, Rubner M F (2008) Surface Functionalization of Living Cells with Multilayer Patches. Nano Letters 8(12): 4446-4453.

Swiston A J, Gilbert J B, Irvine D J, Cohen R E, Rubner M F (2010) Freely Suspended Cellular "Backpacks" Lead to Cell Aggregate Self-Assembly. Biomacromolecules 11(7): 1826-1832.

Teramura Y, Iwata H (2010) Cell surface modification with polymers for biomedical studies. Soft Matter 6(6): 1081-1091.

Teramura Y, Kaneda Y, Iwata H (2007) Islet-encapsulation in ultra-thin layer-by-layer membranes of poly(vinyl alcohol) anchored to poly(ethylene glycol)-lipids in the cell membrane. Biomaterials 28(32): 4818-4825.

Teramura Y, Kaneda Y, Totani T, Iwata H (2008) Behavior of synthetic polymers immobilized on a cell membrane. Biomaterials 29(10): 1345-1355. 
Teramura Y, Oommen O P, Olerud J, Hilborn J, Nilsson B (2013) Microencapsulation of cells, including islets, within stable ultra-thin membranes of maleimide-conjugated PEG-lipid with multifunctional crosslinkers. Biomaterials 34(11): 2683-2693.

Tezgel A O, Telfer J C, Tew G N (2011) De Novo Designed Protein Transduction Domain Mimics from Simple Synthetic Polymers. Biomacromolecules 12(8): 3078-3083.

Thomas J L, Borden K A, Tirrell D A (1996) Modulation of mobilities of fluorescent membrane probes by adsorption of a hydrophobic polyelectrolyte. Macromolecules 29(7): 2570-2576.

Torchilin V P (2012) Multifunctional nanocarriers. Advanced Drug Delivery Reviews 64: 302-315.

Totani T, Teramura Y, Iwata H (2008) Immobilization of urokinase on the islet surface by amphiphilic poly(vinyl alcohol) that carries alkyl side chains. Biomaterials 29(19): 2878-2883.

Tribet C, Vial F (2008) Flexible macromolecules attached to lipid bilayers: impact on fluidity, curvature, permeability and stability of the membranes. Soft Matter 4(1): 68-81.

Tsogas I, Sideratou Z, Tsiourvas D, Theodossiou T A, Paleos C M (2007) Interactive transport of guanidinylated poly(propylene imine)-based dendrimers through liposomal and cellular membranes. Chembiochem 8(15): 1865-1876.

Ukawa M, Akita H, Masuda T, Hayashi Y, Konno T, Ishihara K, Harashima H (2010) 2Methacryloyloxyethyl phosphorylcholine polymer (MPC)-coating improves the transfection activity of GALA-modified lipid nanoparticles by assisting the cellular uptake and intracellular dissociation of plasmid DNA in primary hepatocytes. Biomaterials 31(24): 6355-6362.

Unger T, Oren Z, Shai Y (2001) The effect of cyclization of magainin 2 and melittin analogues on structure, function, and model membrane interactions: Implication to their mode of action. Biochemistry 40(21): 6388-6397.

Veerabadran N G, Goli P L, Stewart-Clark S S, Lvov Y M, Mills D K (2007) Nanoencapsulation of stem cells within polyelectrolyte multilayer shells. Macromolecular Bioscience 7(7): 877-882.

Vial F, Cousin F, Bouteiller L, Tribet C (2009) Rate of Permeabilization of Giant Vesicles by Amphiphilic Polyacrylates Compared to the Adsorption of These Polymers onto Large Vesicles and Tethered Lipid Bilayers. Langmuir 25(13): 7506-7513.

Vial F, Oukhaled A G, Auvray L, Tribet C (2007) Long-living channels of well defined radius opened in lipid bilayers by polydisperse, hydrophobically-modified polyacrylic acids. Soft Matter 3(1): 75-78.

Vial F, Rabhi S, Tribet C (2005) Association of octyl-modified poly(acrylic acid) onto unilamellar vesicles of lipids and kinetics of vesicle disruption. Langmuir 21(3): 853-862.

Vives E, Brodin P, Lebleu B (1997) A truncated HIV-1 Tat protein basic domain rapidly translocates through the plasma membrane and accumulates in the cell nucleus. Journal of Biological Chemistry 272(25): 16010-16017.

Vogel H, Jahnig F (1986) THE STRUCTURE OF MELITTIN IN MEMBRANES. Biophysical Journal 50(4): 573-582.

Walrant A, Correia I, Jiao C-Y, Lequin O, Bent E H, Goasdoue N, Lacombe C, Chassaing G, Sagan S, Alves I D (2011) Different membrane behaviour and cellular uptake of three basic arginine-rich peptides. Biochimica Et Biophysica Acta-Biomembranes 1808(1): 382-393.

Walrant A, Vogel A, Correia I, Lequin O, Olausson B E S, Desbat B, Sagan S, Alves I D (2012) Membrane interactions of two arginine-rich peptides with different cell internalization capacities. Biochimica Et Biophysica Acta-Biomembranes 1818(7): 1755-1763.

Weerakkody D, Moshnikova A, Thakur M S, Moshnikova V, Daniels J, Engelman D M, Andreev O A, Reshetnyak Y K (2013) Family of pH (low) insertion peptides for tumor targeting. Proceedings of the National Academy of Sciences of the United States of America 110(15): 5834-5839. 
Werner M, Sommer J U, Baulin V A (2012) Homo-polymers with balanced hydrophobicity translocate through lipid bilayers and enhance local solvent permeability. Soft Matter 8(46): 11714-11722.

Wieprecht T, Beyermann M, Seelig J (1999) Binding of antibacterial magainin peptides to electrically neutral membranes: Thermodynamics and structure. Biochemistry 38(32): 10377-10387.

Wilson J T, Cui W X, Kozovskaya V, Kharlampieva E, Pan D, Qu Z, Krishnamurthy V R, Mets J, Kumar V, Wen J, Song Y H, Tsukruk V V, Chaikof E L (2011) Cell Surface Engineering with Polyelectrolyte Multilayer Thin Films. Journal of the American Chemical Society 133(18): 7054-7064.

Wimley W C (2010) Describing the Mechanism of Antimicrobial Peptide Action with the Interfacial Activity Model. Acs Chemical Biology 5(10): 905-917.

Yang Z, Sahay G, Sriadibhatla S, Kabanov A V (2008) Amphiphilic Block Copolymers Enhance Cellular Uptake and Nuclear Entry of Polyplex-Delivered DNA. Bioconjugate Chemistry 19(10): 1987-1994.

Yaroslavov A A, Melik-Nubarov N S, Menger F M (2006) Polymer-induced flip-flop in biomembranes. Accounts of Chemical Research 39(10): 702-710.

Ye J, Fox S A, Cudic M, Rezler E M, Lauer J L, Fields G B, Terentis A C (2010) Determination of Penetratin Secondary Structure in Live Cells with Raman Microscopy. Journal of the American Chemical Society 132(3): 980-988.

Yessine M A, Dufresne M H, Meier C, Petereit H U, Leroux J C (2007) Proton-actuated membranedestabilizing polyion complex micelles. Bioconjugate Chemistry 18(3): 1010-1014.

Yessine M A, Leroux J C (2004) Membrane-destabilizing polyanions: interaction with lipid bilayers and endosomal escape of biomacromolecules. Advanced Drug Delivery Reviews 56(7): 999-1021.

Yook S, Jeong J H, Jung Y S, Hong S W, Im B H, Seo J W, Park J B, Lee M, Ahn C H, Lee H, Lee D Y, Byun Y (2012) Molecularly Engineered Islet Cell Clusters for Diabetes Mellitus Treatment. Cell Transplantation 21(8): 1775-1789.

Zasloff M (2002) Antimicrobial peptides of multicellular organisms. Nature 415(6870): 389-395.

Zhang S W, Nelson A, Coldrick Z, Chen R J (2011) The Effects of Substituent Grafting on the Interaction of pH-Responsive Polymers with Phospholipid Monolayers. Langmuir 27(13): 8530-8539.

Ziegler A, Blatter X L, Seelig A, Seelig J (2003) Protein transduction domains of HIV-1 and SIV TAT interact with charged lipid vesicles. Binding mechanism and thermodynamic analysis. Biochemistry 42(30): 9185-9194.

Zorko M, Langel U (2005) Cell-penetrating peptides: mechanism and kinetics of cargo delivery. Advanced Drug Delivery Reviews 57(4): 529-545. 